110 Nordiska ministerrådet

Miljöpåståenden för textilier på den Nordiska marknaden

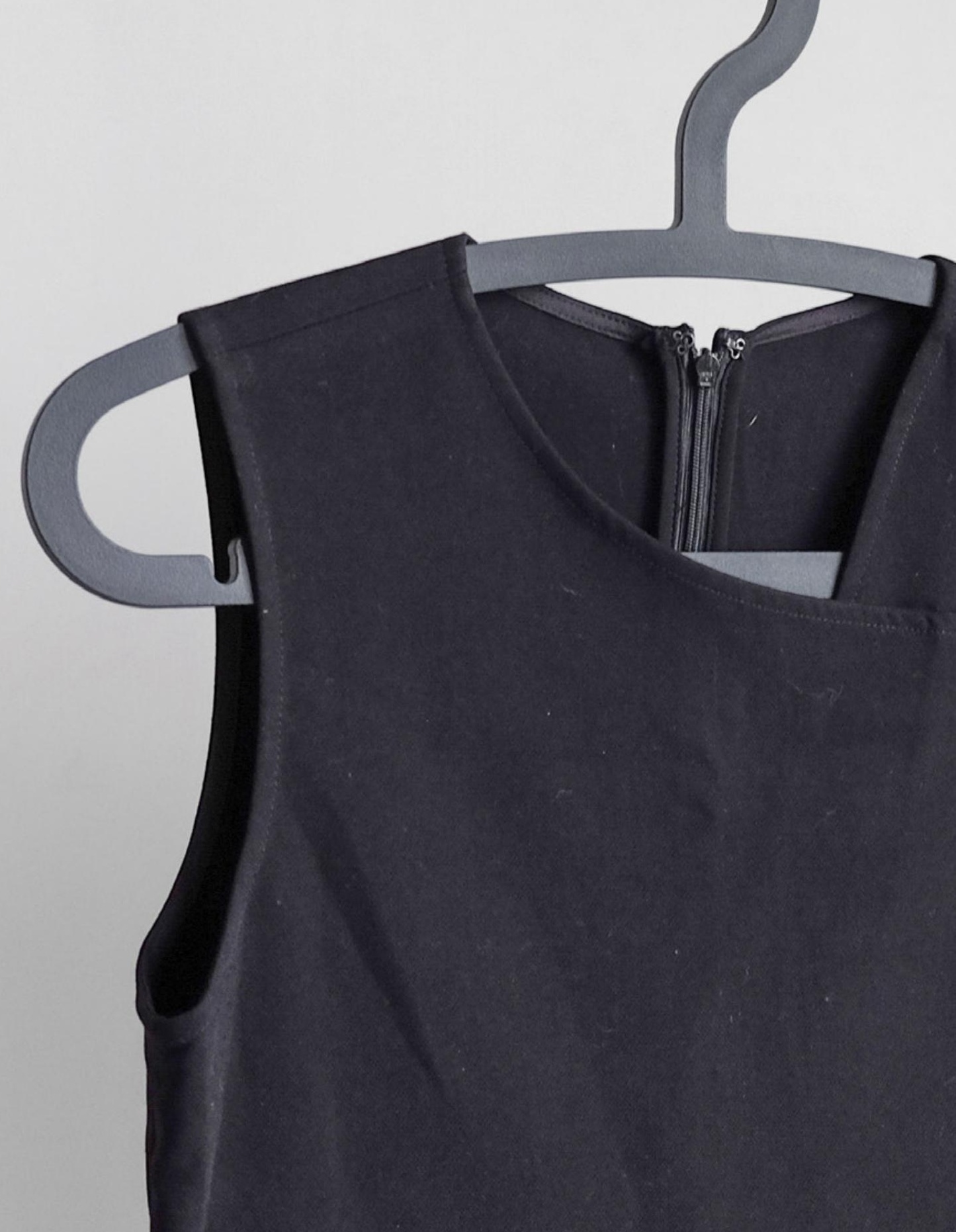





\section{Miljöpåståenden för textilier på den Nordiska marknaden}

David Althoff Palm, Eva Himmelstrup Dahl, Therese Holmgren, Sanna Moliis, Marianne Bigum and David McKinnon

TemaNord 2019:506 


\section{Miljöpåståenden för textilier på den Nordiska marknaden}

David Althoff Palm, Eva Himmelstrup Dahl, Therese Holmgren, Sanna Moliis, Marianne Bigum and David McKinnon

ISBN 978-92-893-6010-4 (PRINT)

ISBN 978-92-893-6011-1 (PDF)

ISBN 978-92-893-6012-8 (EPUB)

http://dx.doi.org/10.6027/TN2019-506

TemaNord 2019:506

ISSN 0908-6692

Standard: PDF/UA-1

ISO 14289-1

(c) Nordisk ministerråd 2019

Cover photo: Unsplash.com

\section{Disclaimer}

This publication was funded by the Nordic Council of Ministers. However, the content does not necessarily reflect the Nordic Council of Ministers' views, opinions, attitudes or recommendations.

Rights and permissions

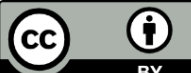

This work is made available under the Creative Commons Attribution 4.0 International license (CC BY 4.0) https://creativecommons.org/licenses/by/4.o.

Translations: If you translate this work, please include the following disclaimer: This translation was not produced by the Nordic Council of Ministers and should not be construed as official. The Nordic Council of Ministers cannot be held responsible for the translation or any errors in it.

Adaptations: If you adapt this work, please include the following disclaimer along with the attribution: This is an adaptation of an original work by the Nordic Council of Ministers. Responsibility for the views and opinions expressed in the adaptation rests solely with its author(s). The views and opinions in this adaptation have not been approved by the Nordic Council of Ministers.

Third-party content: The Nordic Council of Ministers does not necessarily own every single part of this work. The Nordic Council of Ministers cannot, therefore, guarantee that the reuse of third-party content does not infringe the copyright of the third party. If you wish to reuse any third-party content, you bear the risks associated with any such rights violations. You are responsible for determining whether there is a need to obtain permission for the use of third-party content, and if so, for obtaining the relevant permission from the copyright holder. Examples of third-party content may include, but are not limited to, tables, figures or images. 
Photo rights (further permission required for reuse):

Any queries regarding rights and licences should be addressed to:

Nordic Council of Ministers/Publication Unit

Ved Stranden 18

DK-1061 Copenhagen K

Denmark

Phone +4533960200

pub@norden.org

\section{Nordic co-operation}

Nordic co-operation is one of the world's most extensive forms of regional collaboration, involving Denmark, Finland, Iceland, Norway, Sweden, and the Faroe Islands, Greenland and Åland.

Nordic co-operation has firm traditions in politics, economics and culture and plays an important role in European and international forums. The Nordic community strives for a strong Nordic Region in a strong Europe.

Nordic co-operation promotes regional interests and values in a global world. The values shared by the Nordic countries help make the region one of the most innovative and competitive in the world.

\section{The Nordic Council of Ministers}

Nordens Hus

Ved Stranden 18

DK-1061 Copenhagen K, Denmark

Tel.: +4533960200

www.norden.org

Download Nordic publications at www.norden.org/nordpub 



\section{Innehåll}

Förord

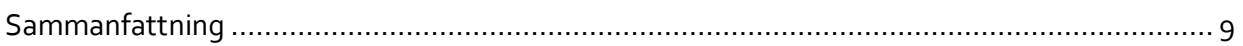

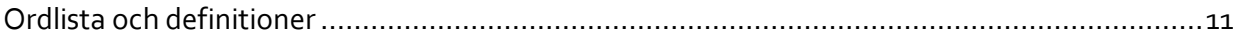

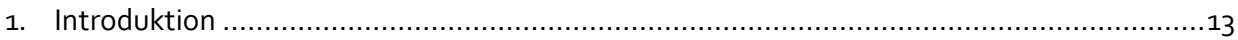

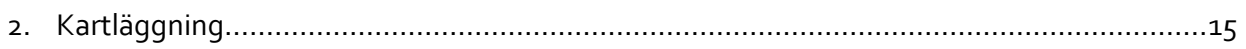

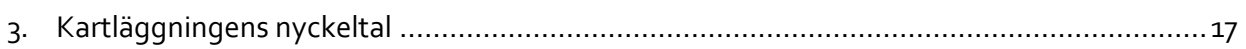

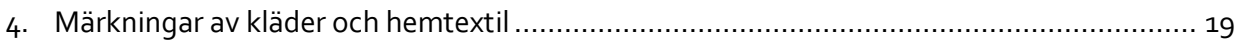

4.1 Branschens svårigheter med märkning ........................................................ 19

4.2 Bra aktiviteter som blir sämre märkningar ...................................................... 20

4.3 Märkningens roll för en minskad miljöbelastning ............................................ 20

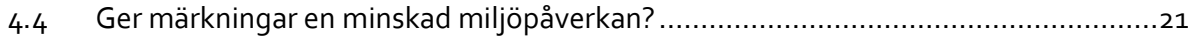

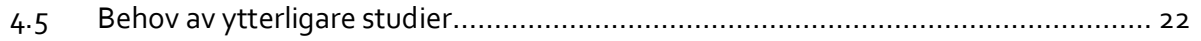

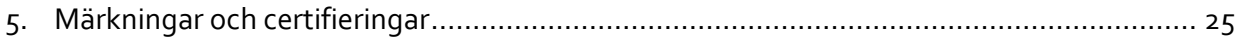

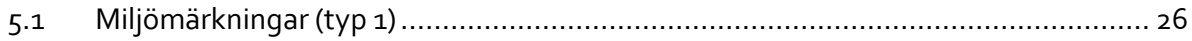

5.2 Branschstandarder med krav på tredjepartscertifiering/-verifiering .........................27

5.3 Företagens egna miljöuttalanden (typ 2) utan krav på

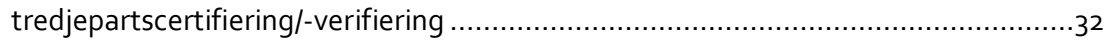

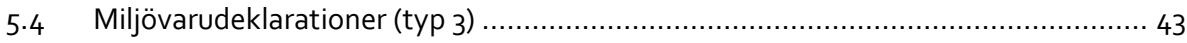

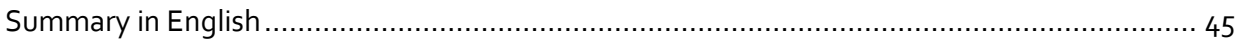




\section{Förord}

Alla olika steg i den textila värdekedjan påverkar miljön på ett eller annat sätt. Detta är ett problem som uppmärksammas mer och mer idag på samma gång som vår konsumtion av textilier ökar både i form av kläder och hemtextilier.

Textilbranschen är medveten om denna negativa miljöpåverkan och vill på olika sätt vägleda konsumenten till bättre val. Även organisationer och andra intressenter vill informera och ge konsumenter verktyg för att vid sina kläd- och textila inköp välja det som påverkar miljön mindre.

I denna goda vilja från olika håll kan det bli rörigt för konsumenten med tanke på alla olika informations- och kommunikationsverktyg som märkningar, miljöpåståenden, associationer/argument med mera som konsumenten möter i kläd- och textil sammanhang. Det är också svårt för konsumenten att avgöra transparens, effekt och trovärdighet av det den möts av och risken är att det man trodde var ett medvetet val kanske inte ger den effekt med mera som utlovats.

Arbetsgruppen Hållbar konsumtion och produktion (HKP) inom Nordiska ministerrådet för miljö och klimat har initierat detta projekt med avsikten att scanna av den nordiska textilmarknaden med fokus på de märkningar, miljöpåståenden med mera som konsumenten möter. Genom att strukturera och ge kort information om de märkningar och miljöpåståenden som hittas får vi ett underlag som kan användas för vidare studier och analys. Resultatet är framförallt tänkt att användas av miljö- och konsumentorganisationer och myndigheter på olika nivåer i de nordiska länderna i syfte att hjälpa konsumenten till medvetna val och att inte bli vilseledd.

Eventuella åsikter, värderingar och slutsatser som kan uppfattas i rapporten är konsultens egna. Arbetsgruppen HKP ser struktureringen som en objektiv framställning av funna märkningar och miljöpåståenden och anser att vidare och djupare studier behövs för att analysera och värdera varje märke/påståendes positiva, negativa eller "ingen påverkan alls" effekt samt om de kan vara vilseledande eller till en hjälp för konsumenten som vill göra medvetna val.

Katarina Järverup Frisk

Ordförande, Nordiska HKP gruppen

Handläggare Hållbarhetsenheten, Naturvårdsverket, Karlstad 


\section{Sammanfattning}

Denna rapport kartlägger en stor mängd av de miljömärkningar och miljöuttalanden som används framförallt på hemtextil och kläder på den Nordiska marknaden. Syftet med studien har varit att samla ett kunskapsunderlag kring vilka miljömärkningar och miljöuttalanden som används på textil i Norden; hur de används och hur de kan bidra till en minskad miljöbelastning. Målet har varit att skapa en strukturerad och tydlig inventering av tillgängliga märkningar som grund för vidare studier och arbete inom nationella konsumentorganisationer som kan vara myndigheter eller frivilligorganisationer.

Kartläggningen har inkluderat 56 märkningar och miljöuttalanden.

En märkning kan beröra en enskild miljöaspekt eller var övergripande för en hel produktionskedja med aspekter inom kemikalier, energianvändning, produktionsutsläpp, utsläpp vid användning med flera. Det är därför inte möjligt att baserat på denna studie avgöra vilken märkning som ställer högst krav på en produkt. En märkning visar på en specifik miljöpåverkan eller flera miljöpåverkansområden där produkten har en bättre prestanda än motsvarande standardprodukt på marknaden. 


\section{Ordlista och definitioner}

$\mathrm{BCl}$

OCS

RCS

GRS

GOTS

CmiA

JRC

Märkning

Miljömärkning

Vedertagen Branschstandard

Miljöuttalanden
Better Cotton Initiative (Better Cotton)

Organic Cotton Standard

Recycled Claims Standard

Global Recycle Standard

Global Organic Textile Standard

Cotton made in Africa

Joint Research Centre

Samlingsord för miljömärkning, miljöuttalanden och miljödeklarationer

Tredjepartsgranskad märkning enligt ISO 14024

Tredjepartsgranskad märkning

Företagens egna miljöuttalanden 


\section{Introduktion}

Denna rapport kartlägger en stor mängd av de miljömärkningar, certifieringar och miljöuttalanden som används på kläder och hemtextil på den Nordiska marknaden. Studien har genomförts av Ramboll under 2018 på uppdrag av arbetsgruppen Hållbar Konsumtion och Produktion under Nordiska Ministerrådet.

Syftet med studien har varit att samla ett kunskapsunderlag kring vilka miljömärkningar och miljöuttalanden som används på textil i Norden; hur de används och hur de kan användas för att bidra till en minskad miljöbelastning. Målet har varit att skapa en strukturerad och tydlig inventering av tillgängliga märkningar som grund för vidare studier och arbete inom nationella konsumentorganisationer som kan vara myndigheter eller frivilligorganisationer.

Av bildrättighetsskäl kan tyvärr inte studerade märkningars logotyper visas i denna rapport. Även om författarna har gjort sitt yttersta för att inga felaktigheter ska förekomma i rapporten går det aldrig att utesluta. 


\section{Kartläggning}

Kartläggningen av märkningar har skett huvudsakligen genom webbsökningar, butiksbesök och kontakter med branschorganisationer och experter i Sverige, Norge, Finland och Danmark. Inga intervjuer har skett med enskilda företag annat än med butikspersonal som getts möjlighet att förklara märkningar eller dela ut material. Samtliga kontakter och sökningar har genomförts under perioden juni-november 2018 och baseras på den information som fanns tillgänglig under denna tidsperiod.

Information om märkningar i butik har identifierats genom att studera

- själva märkningen

- eventuellt uppsatta skyltar i butiken

- eventuella broschyrer i butiken

- butikspersonalens svar på direkta frågor

- om hänvisning till webbsida gjorts, även på webbsida.

Information om märkningar i nätbutiker har identifierats genom att studera

- information i direkt anslutning till märkningen

- information på separat sida om miljö, hållbarhet eller liknande

- genomsökning av sajt genom extern sökmotor för nyckelord

- för externa märkningar, genom märkningarnas respektive webbsidor.

Märkningarna är uppdelade på fyra typer:

1. "Miljömärkningar" inkluderar märkningar som definieras i ISO14024 (typ 1- program för miljömärkning).

2. "Vedertagna branschstandarder" som ställer krav på tredjepartscertifiering/-verifiering.

3. "Miljöuttalanden" inkluderar ISO14021 (typ 2 - Egna miljöuttalanden) som ofta är enskilda företags egna märkningar.

4. Miljödeklarationer inkluderar ISO14025 (typ 3- miljödeklarationer) som ofta benämns EPD-system. 


\section{Kartläggningens nyckeltal}

Kartläggningen har inkluderat 56 märkningar där en stor andel är företagens egna miljöuttalanden, typ 2. De mest kända märkningarna är däremot av typ 1 och tillhör ett fristående miljömärkningsprogram eller är vedertagna branschstandarder där tredjepartscertifiering/-verifiering krävs. Endast en producent av textilplagg har identifierats där en typ 3 deklaration finns för tre plagg. Ytterligare 13 märkningar har initialt analyserats men inte inkluderats i kartläggningen då de inte används på den Nordiska marknaden, inte är färdigutvecklade eller endast berör andra krav än miljö. Trots att ett stort antal märkningar har identifierats är det endast en mindre del av kläder och hemtextil som säljs med någon form av märkning.

Det är ovanligt med nationella märkningar och endast 7 märkningar (ca 13 \%) av märkningarna är fokuserade till ett enskilt land. Däremot är 19 märkningar (34 \%) främst kopplade till ett eller flera Nordiska länder. 


\section{Märkningar av kläder och hemtextil}

En samlad bild över användandet av de märkningar som identifierats och intervjuer med branschorganisationer ${ }^{1}$ ger en bild av att märkning är vanligast på hemtextil och basplagg där produkterna har längre produktcykler. Den märkning som hittats på flest produkter är också STANDARD 100 by OEKO-TEX som är frekvent använd på hemtextil. Märkningar används också mer frekvent av företag som valt miljö som nischmarknad, vilket ofta är mindre företag ur ett globalt hänseende. För dessa företag är GOTS och BlueSign vanliga märkningar och båda dessa uppfattas som växande. För volymhandeln används främst Better Cotton Initiative som märkning. Den Nordiska märkningen Svanen har ett relativt litet genomslag på textil, framförallt jämfört med andra produktgrupper. Totalt sett bedöms det vara en liten andel textil, och då framförallt kläder, som har en märkning för miljöaspekter vilket överensstämmer väl med EUs tidigare större studie på miljöpåståenden. ${ }^{2}$

\subsection{Branschens svårigheter med märkning}

Det är tydligt att en stor del av branschen har svårt att skilja på olika typer av märkningar. Det är en mycket stor mängd miljöuttalanden som är vaga och utan mer information tillgänglig än $E C O$, Organic Cotton, Hållbart, Responsible och motsvarande. Det är heller inte ovanligt att ett plagg märks med till exempel ekologisk när endast en mindre andel har ekologiskt ursprung. Det är även vanligt att uttrycken förstärks av gröna färger och butikstags i rå kartong för att ge ett miljömässigt hållbart intryck utan egentlig substans. För kläder i snabba modecykler är det tydligt svårt att både hinna med och ekonomiskt kunna räkna hem en typ 1 märkning eller en krävande branschstandard och i en vilja att ändå möta målgruppen som letar efter ett miljömässigt bättre alternativ blir skrivningarna övergripande och vaga.

Som en motstående rörelse finns det inom vissa företag starka drivkrafter att skapa en miljömässigt bättre produktion och slutprodukt. Här är problemet istället att de tredjepartscertifierade märkningar som finns inte täcker hela produktlivscykeln eller inte matchar de frågeställningar som är relevanta för just deras produktion. I dessa fall beskrivs ofta företagets miljöarbete snarare än enskilda märkningar då det hade blivit allt för kostsamt att kombinera flera märkningar på samma plagg, framförallt i relation till

\footnotetext{
${ }^{1}$ Finnish Textile \& Fashion, Svensk Handel Stil, TEKO, Svensk Miljömärkning AB, Dansk Mode \& Tekstil.

${ }^{2}$ https://ec.europa.eu/info/sites/info/files/study_on_environmetal_claims_for_non_food_products_2014_en.pdf
} 
kundens betalningsvilja. Flera intervjuade har även nämnt att djungeln av märkningar gör att mervärdet i försäljningsledet sjunker då det är svårt för konsumenten att urskilja seriös och svåruppnådda märkningar.

\subsection{Bra aktiviteter som blir sämre märkningar}

Det finns ett flertal initiativ och märkningar som har en potentiellt viktig funktion att fylla som aktiviteter för att få textilbranschen mer hållbar, men som inte lämpar sig särskilt väl som märkningar eller miljöargument för enskilda produkter. Det mest framstående exemplet är Better Cotton Initiative $(\mathrm{BCl})$ som förenklat är en metod för miljöledning i bomullsproduktion. Det har genom sitt stora genomslag en stor potential att påverka en större del av bomullsproduktionen men ger i många fall en tveksam information till konsumenterna. BCl ställer generellt inte strikta krav utan utgår från att enskilda företag ska arbeta mot en mer hållbar produktion av bomull. Det innebär att bomull inom $\mathrm{BCl}$ kan vara bättre än konventionell bomull, men skillnaden kan för enskilda producenter vara högst marginell.

$\mathrm{BCl}$ använder även ett system med massbalans, vilket innebär att produkten som har märkningen inte behöver ha någon fysisk koppling till $\mathrm{BCl}$ annat än att säljaren av plagget garanterat motsvarande produktion av BCl-bomull. Detta framgår, trots välformulerade obligatoriska texter för märkningen, inte särskilt tydligt för konsumenten som vill välja en fiber med minskad risk för rester av farliga pesticider eller liknande.

Det är även mycket vanligt att företagen i varierande grad likställer certifierad ekologisk bomull och $\mathrm{BCl}$ som hållbart inköpt bomull, trots att kraven för dessa skiljer sig markant åt. Det får i sin tur följden att vissa bolag har minskat sin användning av ekologisk bomull till fördel för $\mathrm{BCl}$ på senare år och därmed försämrat sin miljöprestanda. Cotton Made in Africa används ibland på liknande sätt och har liknande miljökrav som $\mathrm{BCl}$, men är primärt fokuserat på socialt ansvarstagande.

Bluesign har en liknande form av inkrementell förbättring och inriktningskrav snarare än strikta gränser.

Cradle to Cradle Certification har däremot tydliga kravnivåer och en tydlighet hur ett företag succesivt kan förbättra en produkts prestanda. Detta samtidigt som märkningen bygger på inkrementell förbättring.

\subsection{Märkningens roll för en minskad miljöbelastning}

En miljömärkning eller ett miljöuttalande kan beröra en enskild miljöaspekt eller vara övergripande för en hel produktionskedja med aspekter inom kemikalier, energianvändning, produktionsutsläpp, utsläpp vid användning med flera. Det är därför inte möjligt att baserat på denna studie avgöra vilken märkning som ställer högst krav på en produkt. En korrekt märkning visar på en specifik miljöpåverkan eller flera miljöpåverkansområden där produkten har en bättre prestanda än motsvarande standardprodukt på marknaden. De flesta märkningar gör det därmed bara möjligt att 
visa på att till exempel en ekologiskt odlad bomullsprodukt är miljömässigt bättre än en annan motsvarande bomullsprodukt och detta behöver inte nödvändigtvis betyda att den är bättre än en produkt tillverkad av återvunnen polyester.

Märkningar ska vara tillräckligt transparenta och presenterade på ett sätt som gör det enkelt för konsumenten att se om de endast berör en miljöaspekt eller om de täcker ett bredare spektrum av miljöaspekter. De mer heltäckande märkningarna gör en avvägning mellan olika områden och ställer krav för att säkerställa en bättre prestanda över samtliga områden de täcker in, men det kommer alltid finns olika syn på vilka frågor som bör ges högsta fokus. Det är mycket svårt att prioritera mellan en lokalt förorenad flod där ett begränsat antal människor får en stor livspåverkan och ett koldioxidutsläpp som påverkar globalt men över lång tid och i kombination med andras utsläpp. För märkningar som enbart berör en del av produktens livscykel finns alltid en risk att miljöpåverkan flyttas utanför märkningens systemgräns vilket innebär att miljöpåverkan inte minskar totalt sett. Studien har inte sett några indikationer på märkningar där det är enkelt att flytta miljöpåverkan utanför systemgränsen, men mer detaljerade studier på enskilda märkningar kan bättre identifiera dessa risker.

Tredjepartscertifierade märkningar har en viktig roll att spela då det finns oberoende aktörer som granskar de som använder märkningen vilket ger en trovärdighet som är svårt att uppnå på annat sätt. Dessa märkningar ger också en viss tyngd att de miljöfrågor som inkluderas är relevanta och aktuella. Tredjepartscertifierade märkningar har i normalfallet även tydliga regler för exakt hur märkningar får och ska användas för att inte vilseleda konsumenten.

Den största miljönyttan fås i regel då textil kan användas längre antingen av samma person eller genom second hand eller mindre reparationer. Detta är historiskt inte ett område som miljömärkningar inkluderar men krav har börjat ställas på en lägsta nivå på kvalitet gällande krympning, färg, deformation med mera. Det har också kommit märkningar för rent återbruk där ett second hand plagg kan märkas med relativt få övriga krav än att någon ska ha använt plagget tidigare. Samtidigt kommer inte textil hålla i all evighet och då kan övriga miljömärkningar hjälpa konsumenten att välja det nyproducerade plagg med minsta möjliga miljöpåverkan.

\subsection{Ger märkningar en minskad miljöpåverkan?}

Huruvida märkningar i stort ger en minskad miljöpåverkan är mycket svårt att ge ett tillförlitligt svar på då det varierar mellan olika märkningar, branscher och även över tid. Miljöpåverkan är även ett brett begrepp som inte bara inkluderar klimat utan även vatten, kemikalier och där effekter kan vara lokala, regionala, globala och även vara reversibla eller irreversibla.

Märkningar i oberoende miljömärkningsprogram, typ 1, samt hårt kravställande branschstandarder ställer i huvudsak krav på kemikalieanvändning och utsläpp i någon del av produkternas livscykel och i vissa fall övergripande över hela livscykeln med ett brett spektrum av miljöaspekter. Dessa får anses bidra till en minskad övergripande miljöpåverkan samtidigt som de behöver ha en balans mellan heltäckande krav och 
möjligheten att nå fler produkter för att nå en meningsfull andel av textilmarknaden. För hemtextil verkar detta fungera överlag bra och vissa märkningar har fått större genomslag. För kläder är det tydligt att endast ett fåtal märkningar har något större genomslag och sannolikt krävs det en i grunden ändrad modekonsumtion för att de med någorlunda heltäckande krav ska kunna få ett större genomslag. De snabba modecyklerna gör det svårt och kostsamt att miljömärka plaggen i förhållande till mervärdet i försäljningsledet. De företag som arbetar aktivt med typ 1 märkningarna är ofta globalt sett mindre företag som försöker diversifiera sig på marknaden genom märkningen.

För företagens och delvis branschens egna märkningar, typ 2, är det mer varierande resultat med enskilda märkningar som ger en positiv förenkling där de till exempel samlar flera olika märkningar beroende på vad som är mest intressant för den enskilda produkten. Samtidigt ger den stora mängden svaga eller odefinierade märkningar att konsumenten i stort får svårare att identifiera de produkter där tuffa krav faktiskt uppnåtts. Exemplet där BCl får ett större genomslag och därmed riskerar att minska andelen certifierad ekologisk bomull fås dessutom direkt motsatta effekter. Om dessa märkningar totalt sett har en positiv miljöeffekt är därmed mer osäkert.

En hel del miljöarbete sker även utanför märknings och certifieringssystemen där vissa företag genom stor transparens kring produktionskedjor istället för att nödvändigtvis miljömärka sina plagg skapar möjlighet för oberoende organisationer att granska deras miljöarbete.

Studien har identifierat ett fåtal märkningar där ett mindre fokus finns på långlivade plagg - både ur teknisk- och estetisk hållbarhet som i sig ofta medför en lägre total miljöpåverkan. Det finns här svårigheter att hitta bra universella mätmetoder för dessa faktorer. Exemplet GOTS ${ }^{3}$ har vissa krav kring teknisk hållbarhet, men har i studien varit svårt att avgöra vilken påverkan dessa krav i praktiken har. Det finns även exempel där man helt enkelt redovisar ett oberoende nötningstest på jeans för att indikera en längre teknisk livslängd utan att för den delen skapa en märkning. ${ }^{4}$

\subsection{Behov av ytterligare studier}

Denna kartläggning ger endast information om vilka märkningar som identifierats på den Nordiska marknaden för kläder och hemtextil. Att göra detaljerade granskningar kring hur väl enskilda märkningar uppfyller existerande lagstiftning för marknadsföring skulle ge ytterligare information kring hur branschen skulle kunna arbeta med förbättring och skapa tydligare märkningar.

3 GOTS Krav 5.0 2.2.4.14.

4 https://www.ossoami.com/se/test-barnjeans 
Det finns ett antal bra underlag för denna typ av utvärderingar som kan användas:

- Multi-stakeholder Dialogue on Environmental Claims - MDEC) som gjordes för att stödja implementering och hantering av direktiv 2005/29/EC ger som exempel en förenklad utvärderingsmetodik för transparens, miljöprestanda, presentation och dokumentation.

- EUs studie kring miljöuttalanden för icke-mat produkter ${ }^{6}$ ger också en mycket detaljerad metodik för utvärdering av enskilda märkningar och deras kontext.

- För en komplett juridisk bedömning av en enskild märkning behöver givetvis även praxis genom avgjorda rättsfall och tillsynsärenden beaktas.

5 https://ec.europa.eu/info/live-work-travel-eu/consumers/unfair-treatment/unfair-treatment-policy-information_en

${ }^{6}$ https://ec.europa.eu/info/sites/info/files/study_on_environmetal_claims_for_non_food_products_2014_en.pdf 


\section{Märkningar och certifieringar}

Varje individuell märkning återfinns här med grundläggande information, en beskrivning av huvudbudskap, omfattning, hänvisning till mer information samt en kommentar till dessa. Beskrivning av märkningens huvudbuskap är i möjligaste mån taget direkt från deras egen beskrivande text på webbsida eller i butik och är därför formulerat ur företagets perspektiv i kursiv text. Först återfinns märkningar av typ 1 följt av branschstandarder där samtliga märkningar kräver en tredjepartscertifiering, följt av typ 2 med företagens egna miljöuttalanden och sist typ 3 miljövarudeklarationer. 


\subsection{Miljömärkningar (typ 1)}

Tabell 1: Miljömärkningar (typ 1)

\begin{tabular}{|c|c|c|c|c|c|c|}
\hline $\mathrm{Nr}$ & Märkning & Ägare & Användare & Marknad & Huvudbudskap, omfattning och mer information & Kommentar \\
\hline 1 & $\begin{array}{l}\text { Nordic Swan } \\
\text { Ecolabel/Svanen }\end{array}$ & $\begin{array}{l}\text { Nordiska Ministerrådet } \\
\text { genom nationella } \\
\text { sekretariat }\end{array}$ & $\begin{array}{l}\text { Företag inom både } \\
\text { kläder och hemtextil } \\
\text { Över } 400 \text { märkta } \\
\text { produkter }\end{array}$ & Norden & $\begin{array}{l}\text { Kraven för Svanenmärkta textilier täcker alla stegi } \\
\text { produktionen, inklusive fiberframställning, spinning, } \\
\text { vävning, bleking, infärgning och efterbehandling. } \\
\text { Märkningen gäller kläder och hemtextil och har ett } \\
\text { livscykelperspektiv även om vissa krav endast gäller } \\
\text { dokumentation. } \\
\text { Märkningen finns både på tags på kläder och på websidor. } \\
\text { Information om märkningen finns på websidan: } \\
\text { http://www.svanen.se/ }\end{array}$ & $\begin{array}{l}\text { Nordiska Svanen finns på ett stort antal produktgrupper } \\
\text { och det är mycket lätt att hitta vilka krav som ställs på } \\
\text { produkterna. Märkningen gäller framförallt innehåll och } \\
\text { utsläpp av kemiska ämnen men även andra kriterier finns. } \\
\text { Kraven är omfattande och dokumentationen visar på en } \\
\text { tydlig miljönytta jämfört med en standardprodukt. Det } \\
\text { finns tydliga regler för hur märkningen făr användas i } \\
\text { marknadsföring. }\end{array}$ \\
\hline 2 & $\begin{array}{l}\text { EU-Ecolabel/ } \\
\text { EU-blomman }\end{array}$ & $\begin{array}{l}\text { EU genom } \\
\text { medlemsstater eller } \\
\text { dess representanter }\end{array}$ & $\begin{array}{l}\text { Företag inom både } \\
\text { kläder och hemtextil }\end{array}$ & EU & $\begin{array}{l}\text { Den överordnade visionen för våra miljömärkningar är ett } \\
\text { hållbart samhälle. När vi tar fram krav arbetar vi } \\
\text { transparent. Vi konsulterar experter på området, frågar } \\
\text { branschen om råd och tar in synpunkter från alla som är } \\
\text { intresserade. På så sätt vill viförsäkra oss om att kraven blir } \\
\text { så tuffa och så bra som möjligt. } \\
\text { Märkningen gäller kläder och hemtextil och har ett } \\
\text { livscykelperspektiv. } \\
\text { Märkningen finns både på tags på kläder och på websidor. } \\
\text { Information om märkningen finns på websidan: } \\
\text { https://www.svanen.se/Vara-krav/EU-blommans-kriterier/ } \\
\text { http://ec.europa.eu/environment/ecolabel/ }\end{array}$ & $\begin{array}{l}\text { Kriterierna tas fram av EUs Joint Research Centre (JRC) } \\
\text { och inkluderar både miljö och kvalitetskrav. Kraven som } \\
\text { ställs beskrivs både mycket övergripande i broschyrer, } \\
\text { något mer detaljerat i faktablad och finns tillgängliga i } \\
\text { komplett format. En mindre minus att faktabladen inte } \\
\text { nås direkt från sidan som är riktad mot konsumenter utan } \\
\text { först på sidan för företag eller sidan för listade produkter. } \\
\text { Det finns tydliga regler för hur märkningen får användas i } \\
\text { marknadsföring. }\end{array}$ \\
\hline 3 & Bra Miljöval & Naturskyddsföreningen & $\begin{array}{l}\text { Företag inom både } \\
\text { kläder och hemtextil }\end{array}$ & Sverige & $\begin{array}{l}\text { Märkningen Bra Miljöval säkerställer att kläder och textilier } \\
\text { tillverkas på ett schysst sätt. Vår miljömärkning gör att du } \\
\text { kan välja de produkter som är minst skadliga för miljön. } \\
\text { Märkningen gäller kläder och hemtextil och har ett } \\
\text { livscykelperspektiv. } \\
\text { Märkningen finns både på tags på kläder och på websidor. } \\
\text { Information om märkningen finns på websidan: } \\
\text { https://www.naturskyddsforeningen.se/bra-miljoval/textil }\end{array}$ & $\begin{array}{l}\text { Märkningen beskrivs i enkla informationsblad, foldrar och } \\
\text { med kompletta kriterier. Kraven är liknande GOTS men } \\
\text { med några ytterligare kriterier och täcker hela } \\
\text { produktionskedjan. Det finns tydliga regler för hur } \\
\text { märkningen får användas i marknadsföring. Det är troligen } \\
\text { lite svårt att tolka skillnaden mellan klass } 1 \text { och } 2 \text { i } \\
\text { märkningen vid köpögonblicket då märkningarna är } \\
\text { väldigt lika. Kriterierna kontrollerades senast för } 3 \text { år } \\
\text { sedan för giltighet. Det finns även krav för återanvänd och } \\
\text { återtillverkad textil. }\end{array}$ \\
\hline
\end{tabular}




\subsection{Branschstandarder med krav på tredjepartscertifiering/-verifiering}

Tabell 2: Branschstandarder med krav på tredjepartscertifiering/-verifiering

\begin{tabular}{|c|c|c|c|c|c|c|}
\hline $\mathrm{Nr}$ & Märkning & Ägare & Användare & Marknad & Huvudbudskap, omfattning och mer information & Kommentar \\
\hline 1 & $\begin{array}{l}\text { Global Organic Textile } \\
\text { Standard-GOTS }\end{array}$ & $\begin{array}{l}\text { OTA (USA), IVN } \\
\text { (Germany), Soil } \\
\text { Association (UK) and } \\
\text { JOCA (Japan) }\end{array}$ & $\begin{array}{l}\text { Företag inom både } \\
\text { kläder och hemtextil }\end{array}$ & Global & $\begin{array}{l}\text { Definierar globalt erkända krav för ekologisk } \\
\text { framställning av textil. } \\
\text { Märkningen som konsumenten möter gäller kläder och } \\
\text { hemtextil. Det finns även märkning av fibrer och } \\
\text { produktionsanläggningar för företagskommunikation } \\
\text { t.ex. för att kunna spåra ekologisk fiber. Märkningen har } \\
\text { ett livscykelperspektiv men med fokus på ekologisk } \\
\text { odling. } \\
\text { Märkningen finns både på tags i butiker och på } \\
\text { websidor. } \\
\text { Information om märkningen finns på websidan: } \\
\text { http://www.global-standard.org }\end{array}$ & $\begin{array}{l}\text { GOTS har tydligt redovisade krav för kemikalier, } \\
\text { avloppsrening från anläggningar m.m. med tydliga } \\
\text { granskningsprocedurer och beskriver kraven både } \\
\text { översiktligt och detaljerat på ett transparent och tydligt } \\
\text { sätt. GOTS ställer krav från odling till färdig produkt. } \\
\text { GOTS har även vissa kvalitetskrav på färdiga plagg för } \\
\text { längre estetisk och funktionell livslängd. En GOTS-märkt } \\
\text { produkt måste innehållla minst } 70 \% \text { GOTS-märkt } \\
\text { ekologisk råvara. Det finns tydliga regler för hur } \\
\text { märkningen får användas i marknadsföring. }\end{array}$ \\
\hline 2 & $\begin{array}{l}\text { IVN Certified Best } \\
\text { NATURTEXTIL }\end{array}$ & $\begin{array}{l}\text { Internationalen } \\
\text { Verband der } \\
\text { Naturtextilwirtschaft e. } \\
\text { V. (IVN) }\end{array}$ & $\begin{array}{l}\text { Företag inom både } \\
\text { kläder och hemtextil } \\
\text { tillverkade av främst } \\
\text { naturfibrer }\end{array}$ & Europa & $\begin{array}{l}\text { Kvalitetsstandarden IVN Certified Best NATURTEXTIL, } \\
\text { främst känd inom Europa, definierar nulägets högsta nivå } \\
\text { av textil hållbarhet genom att kräva högsta möjliga } \\
\text { nåbara kravparametrar på produktion och produkt. } \\
\text { Märkningen gäller kläder och hemtextil tillverkade av } \\
\text { främst naturfibrer och har ett livscykelperspektiv men är } \\
\text { inte heltäckande för t.ex. klimatpåverkan. } \\
\text { Information om märkningen finns på websidan: } \\
\text { https://naturtextil.de/en//ivn-quality-seals/about- } \\
\text { naturtextil-ivn-zertifiziert-best/ }\end{array}$ & $\begin{array}{l}\text { Märkningen är väldokumenterad och har tuffa krav } \\
\text { gällande kemikalieanvändning och lokalt påverkande } \\
\text { utsläpp. Om dessa är högsta nivå är svårt att avgöra, men } \\
\text { de verkar vara högt satta. Det ställs endast inriktningskrav } \\
\text { på energianvändning och inga krav på klimatpåverkan. } \\
\text { Dokumentationen är detaljerad och finns även i mer } \\
\text { lättillgängliga beskrivningar. }\end{array}$ \\
\hline 3 & $\begin{array}{l}\text { STANDARD } 100 \text { by } \\
\text { OEKO-TEX }\end{array}$ & $\begin{array}{l}\text { OEKO-TEX® } \\
\text { Association }\end{array}$ & $\begin{array}{l}\text { Företag inom både } \\
\text { kläder och hemtextil, } \\
\text { främst det senare }\end{array}$ & Global & $\begin{array}{l}\text { Världens ledande märkning för textil och textilliknande } \\
\text { produkter som undersöks för hälso-och miljöfarliga } \\
\text { ämnen. } \\
\text { Märkningen gäller kläder och hemtextil och avser } \\
\text { endast möjlig hälsopåverkan på användaren till följd av } \\
\text { textilens emitterande ämnen vid användning. } \\
\text { Märkningen finns ofta på insydd lapp i plaggen samt på } \\
\text { tags och på websidor. } \\
\text { Information om märkningen finns på websidan: } \\
\text { https://www.oeko-tex.com/en/business/certifications_a } \\
\text { nd_services/ots_10o/ots_10o_start.xhtml }\end{array}$ & $\begin{array}{l}\text { Märkningen fokuserar på ämnen som kan påverka de som } \\
\text { använder produkterna, det vill säga främst hälsofarliga } \\
\text { ämnen vid användning. Märkningen ställer inga krav på } \\
\text { produktion utan endast på slutprodukt. Detta framgår } \\
\text { tydligt och det finns lättillgänglig och lättfattlig } \\
\text { information om vad märkningen innebär. Strikta krav på } \\
\text { emissioner från slutprodukten har sannolikt en påverkan } \\
\text { på vilka ämnen som används vid produktion samt bidrar } \\
\text { till mer giftfria textilier vid återvinning. Flera fall har } \\
\text { identifierats där företag använder märkningen OEKO-TEX } \\
\text { på websidor utan att specificera vilken av OEKO-TEX- } \\
\text { märkningarna som avses. }\end{array}$ \\
\hline
\end{tabular}


En oberoende certifiering av den textila värdekedjan för att analysera, certifiera och optimera den utifrån hällbarhet och socialt ansvarstagande produktion. Märkning avser produktion av textil och är ej en ren produktmärkning.

Information om märkningen finns på websidan:

http://www.oeko-tex.com/en/business/certifications_an d_services/step_by_oeko_tex/step_start.xhtml

En oberoende märkning av textilprodukter som är testade förhållanden.

\section{Märkningen}

gäller kläder och hemtextil och har ett livscykelperspektiv.

Märkningen finns på tags och på websidor.

Information om märkningen finns på websidan:

http://www.oeko-tex.com/en/business/certifications_an d_services/mig/mig_start.xhtml

Skapar en koppling mellan utsatta bomullsodlare och konsumenten för att skapa rättvisa affärsvillkor och stärka odlarna och deras anställda att få kontroll över sina liv. Att minska direkt miljöpåverkan som påverkar odlarnas hälsa och liv.

Märkningen gäller bomull i kläder och hemtextil och inkluderar lokal miljöpåverkan vid odling av bomull. Märkningen finns på tags och på websidor.

Information om märkningen finns på websidan: https://www.fairtrade.net/products/cotton.html

Skapar en koppling mellan utsatta textilarbetare och konsumenten för att skapa rättvisa affärsvillkor och stärka tillverkarna och deras anställda med bättre löner och arbetsvillkor. Att minska negativ påverkan på arbetare och miljö genom kontroll av kemikalieanvändning och arbetssätt. Märkningen gäller kläder och hemtextil och inkluderar lokal miljöpåverkan vid framställning av textil. Märkningen finns på tags och på websidor. Information om märkningen finns på websidan

https://www.fairtrade.net/standards/ourstandards/textile-standard html
Kommentar

Märkningen får endast användas mellan företag och få inte riktas direkt till konsumenter. Det krävs ganska mycket läsning för att hitta detta faktum och om man stöter på (en felaktigt använd) märkning är det svårt att upptäcka detta. Företag som når en högre hållbarhetsnivå belönas med färre onnnonserade inspektioner.

Märkningen samlar kraven för produktionscertifiering OEKO-TEX STeP och certifieringen för farliga ämnen STANDARD 100 by OEKO-TEX. Underliggande krav är tydliga och transparenta och miljönyttan jämfört med standardprodukt är tydlig, men i presentationen anges att godkända produkter är "miljövänliga".

Kommentaren berör inte kraven på social hållbarhet. Det är mycket svårt att följa vilka krav som ställs specifikt pa bomull och hur de kopplar till Fairtrades standard för textilproduktion då fokus är på enskilda exempel och känsloinriktad marknadsföring. Miljökraven är väldigt grundläggande och har många undantag beroende på lokala förutsättningar, vilket troligen är nödvändigt med märkningens fokus. Miljökraven fokuserar helt på lokal miljöpåverkan ur perspektivet att på kort och lång sikt skydda odlarna. Detta gör att miljönyttan med en Fairtrade Cotton-märkt produkt inte behöver vara bättre än en standardprodukt. Märkningen verkar inte göra starka miljöuttalanden där dokumentation saknas.

Kommentaren berör inte kraven på social hållbarhet. Miljökraven är väldigt grundläggande och har många undantag beroende på lokala förutsättningar, vilket troligen är nödvändigt med märkningens fokus. Detta gö att miljönyttan med en Fairtrade Textile Productionmärkt produkt inte behöver vara bättre än en standardprodukt. Märkningen verkar inte göra starka miljöuttalanden där dokumentation saknas. 


\begin{tabular}{|c|c|c|c|c|c|c|}
\hline $\mathrm{Nr}$ & Märkning & Ägare & Användare & Marknad & Huvudbudskap, omfattning och mer information & Kommentar \\
\hline 8 & $\begin{array}{l}\text { Global Recycled } \\
\text { Standard }\end{array}$ & Textile Exchange & $\begin{array}{l}\text { Företag som säljer textil } \\
\text { som innehåller } \\
\text { återvunnen råvara }\end{array}$ & Global & $\begin{array}{l}\text { Märkningen certifierar återvunnet innehåll ienskilda } \\
\text { textilprodukter (som produktmärkning) eller företag (som } \\
\text { ej får sätttas på enskilda produkter), och inkluderar } \\
\text { milijökrav och kemikalierestriktioner med målet att öka } \\
\text { användningen av återvunnen råvara och minska eller } \\
\text { elimininera negativ påverkan frän dess produktion. } \\
\text { Märkningen kan användas på kläder och hemtextil som } \\
\text { innehåller minst } 50 \% \text { återvunnet material eller av } \\
\text { företag som totalt sett har minst } 20 \% \text { återvunnet } \\
\text { material i isina produkter. Märkningen har till viss del ett } \\
\text { livscykelperspektiv. } \\
\text { Märkningen finns på produkter och i } \\
\text { företagspresentationer beroende på vilket krav som } \\
\text { uppfylls. Information om märkningen finns på } \\
\text { websidan: } \\
\text { https://textileexchange.org/integrity/ }\end{array}$ & $\begin{array}{l}\text { Märkningen sätter grundläggande krav utöver återvunnet } \\
\text { innehåll och dessa gäller oavsett om det är märkning av } \\
\text { företag eller produkter. Underlaget till märkningen är } \\
\text { mycket tydligt med att eventuellt andra aspekter inte får } \\
\text { användas på ett sätt som kan förknippas med } \\
\text { märkningen. En mindre anmärkning på dokumentation är } \\
\text { att märkningen får användas i sammanhang där ett } \\
\text { företags framtida ambition kommuniceras snarare än } \\
\text { faktisk prestanda. Dock endast på ett sådant sätt att det } \\
\text { tydligt framgår att det är en framtida ambition och detta } \\
\text { får inte göras på enskilda produkter. }\end{array}$ \\
\hline 9 & $\begin{array}{l}\text { Recycled Claim } \\
\text { Standard }\end{array}$ & Textile Exchange & $\begin{array}{l}\text { Företag som säljer textil } \\
\text { som innehåller } \\
\text { återvunnen råvara }\end{array}$ & Global & $\begin{array}{l}\text { Märkningen certifierar återvunnet innehåll i } \\
\text { textilprodukter för att säkerställa att produkten innehåller } \\
\text { àtervunnet material. } \\
\text { Märkningen används på kläder och hemtextil med } \\
\text { nivåerna Recycled blended med minst } 5 \% \text { återvunnet } \\
\text { material och Recycled } 100 \text { med minst } 95 \% \text { återvunnet } \\
\text { material. Märkningen avser endast återvunnet innehăll. } \\
\text { Märkningen finns på tags och på websidor. } \\
\text { Information om märkningen finns på websidan: } \\
\text { https://textileexchange.org/integrity/ }\end{array}$ & $\begin{array}{l}\text { Märkningen har två nivåer där Recycled blended med } 5 \% \\
\text { återvunnet material tveksamt är signifikant nog för att } \\
\text { särskiljas från en standardprodukt. En exakt gräns är svårt } \\
\text { att definiera, och märkning online kräver att andel } \\
\text { återvunnet ska anges, medan märkning i butik inte kräver } \\
\text { detta. Recycled 10o med } 95 \% \text { återvunnet material visar } \\
\text { tydligare på miljönytta. En mindre anmärkning på } \\
\text { dokumentation är att märkningen får användas i } \\
\text { sammanhang där ett företags framtida ambition } \\
\text { kommuniceras snarare än faktisk prestanda. Detta får } \\
\text { dock endast göras på ett sådant sätt att det tydligt } \\
\text { framgår att det är en framtida ambition ("Till } 2020 \\
\text { kommer go \% av våra produkter vara certifierade enligt } \\
\text { RCS.") och får inte göras på enskilda produkter. }\end{array}$ \\
\hline 10 & $\begin{array}{l}\text { Organic Content } \\
\text { Standard }\end{array}$ & Textile Exchange & $\begin{array}{l}\text { Företag som säljer textil } \\
\text { som innehåller } \\
\text { ekologiskt odlad fiber }\end{array}$ & Global & $\begin{array}{l}\text { Märkningen certifierar ekologiskt innehåll i } \\
\text { textilprodukter. } \\
\text { Märkningen används på kläder och hemtextil med } \\
\text { nivåerna Organic blended med minst } 5 \% \text { ekologiskt } \\
\text { material och Organic } 100 \text { med minst } 95 \% \text { ekologiskt } \\
\text { material. Märkningen avser endast ekologiskt odlad } \\
\text { fiber. } \\
\text { Märkningen finns på tags och på websidor. } \\
\text { Information om märkningen finns på websidan: } \\
\text { https://textileexchange.org/integrity/ }\end{array}$ & $\begin{array}{l}\text { Märkningen har två nivåer där Organic blended med } 5 \% \\
\text { återvunnet material tveksamt är signifikant nog för att } \\
\text { särskiljas från en standardprodukt. En exakt gräns är svårt } \\
\text { att definiera, och märkningen kräver att andel ekologiskt } \\
\text { innehåll ska anges. Organic 10o med minst } 95 \% \\
\text { återvunnet material visar på en tydligare miljönytta. En } \\
\text { mindre anmärkning på dokumentation är att märkningen } \\
\text { får användas i sammanhang där ett företags framtida } \\
\text { ambition kommuniceras snarare än faktisk prestanda. } \\
\text { Detta făr dock endast göras på ett sådant sätt att det } \\
\text { tydligt framgår att det är en framtida ambition ("Till } 2020 \\
\text { kommer go \% av våra produkter vara certifierade enligt } \\
\text { OCS.") och făr inte göras på enskilda produkter. }\end{array}$ \\
\hline
\end{tabular}




\begin{tabular}{|c|c|c|c|c|c|c|}
\hline $\mathrm{Nr}$ & Märkning & Ägare & Användare & Marknad & Huvudbudskap, omfattning och mer information & Kommentar \\
\hline 11 & Bluesign & Bluesign systems & $\begin{array}{l}\text { Företag som säljer eller } \\
\text { tillverkar textil }\end{array}$ & Global & $\begin{array}{l}\text { Bluesign är lösningen för hållbar textilproduktion. } \\
\text { Bluesign eliminerar farliga ämnen direkt ibörjan av } \\
\text { produktionsprocesserna och sätter kontrollerade } \\
\text { standarder för en miljövänlig och säker produktion. } \\
\text { Märkningen gäller kläder och hemtextil. och har troligen } \\
\text { ett livscykelperspektiv. } \\
\text { Märkningen finns på tags och på websidor. } \\
\text { Information om märkningen finns på websidan: } \\
\text { https://www.bluesign.com/consumer.html }\end{array}$ & $\begin{array}{l}\text { Bluesign har ingen öppen tillgänglig dokumentation av } \\
\text { vilka krav som ställs utan formulerar övergripande krav } \\
\text { som BAT och ett det finns kemikalierestriktioner. Bluesign } \\
\text { uppmuntrar till kontinuerligt förbättrad miljöprestanda, } \\
\text { men verkar inte ställa tydliga krav. Övergripande principer } \\
\text { är överlag rimliga, men de är vagt formulerade och utan } \\
\text { transparens kring kriterier är det svårt att avgöra om en } \\
\text { bluesignmärkt produkt är bättre än en standardprodukt. }\end{array}$ \\
\hline 12 & $\begin{array}{l}\text { Cradle to Cradle } \\
\text { certified }\end{array}$ & $\begin{array}{l}\text { Cradle to Cradle } \\
\text { Products Innovation } \\
\text { Institute }\end{array}$ & $\begin{array}{l}\text { Företag som säljer eller } \\
\text { tillverkar textil }\end{array}$ & Global & $\begin{array}{l}\text { Produktstandarden Cradle to Cradle certified guidar } \\
\text { designers och tillverkare ien kontinuerlig } \\
\text { förbättringsprocess inom hälsosamma material, } \\
\text { materialutnyttjande, förnybar energi och klimat, } \\
\text { vattenanvändning och social rättvisa för produkter. Varje } \\
\text { kategori betygsätt som bas, brons, silver, guld eller } \\
\text { platinum och lägsta betyget ger totalbetyget. Certifierade } \\
\text { produkter måste visa på förbättrad prestanda vartannat } \\
\text { år. } \\
\text { Märkningen gäller kläder och hemtextil och har ett } \\
\text { livscykelperspektiv. } \\
\text { Märkningen finns på tags (om högre nivå än basic) och } \\
\text { på websidor. } \\
\text { Information om märkningen finns på websidan: } \\
\text { https://www.czccertified.org/get-certified/product- } \\
\text { certification }\end{array}$ & $\begin{array}{l}\text { Produktstandarden är både ett sätt för företagen att } \\
\text { succesivt förbättra miljöprestandan för sina produkter och } \\
\text { då olika kravnivåer nås även märka produkterna med en } \\
\text { nivåmärkning. Kraven för de lägre betygsnivåerna är inte } \\
\text { tydligt högre än en standardprodukt, men det } \\
\text { kommuniceras heller inte som hög nivå. Användning av } \\
\text { märkningen vid basnivå är också mer reglerat än högre } \\
\text { resultat. För att klara högre nivåer ökar den absoluta } \\
\text { kravnivån för produkten. Det är tydligt presenterat både } \\
\text { förenklat och i detalj vilka krav som finns och hur } \\
\text { märkningen får kommuniceras medan miljönytta kan vara } \\
\text { osäker på de lägre nivåerna. }\end{array}$ \\
\hline 13 & Naturland Textiles & Naturland & $\begin{array}{l}\text { Företag som producerar } \\
\text { eller säljer textil } \\
\text { tillverkad av naturliga } \\
\text { fibrer }\end{array}$ & Global & $\begin{array}{l}\text { Naturland är i grunden en förening för ekobönder som } \\
\text { certifierar ekologisk odlade fibrer för textil och } \\
\text { tillverkningsprocessen för textil. Standarden täcker EUs } \\
\text { regler för ekologisk odling och har ytterligare krav både på } \\
\text { odling och på tillverkning av textil. } \\
\text { Märkningen gälller naturfiber i kläder och hemtextil och } \\
\text { avser krav vid ekologisk odling samt innehåll i det } \\
\text { färdiga plagget. } \\
\text { Märkningen finns på tags och på websidor. } \\
\text { Information om märkningen finns på websidan: } \\
\text { https://www.naturland.de/en/ }\end{array}$ & $\begin{array}{l}\text { Naturland visar tydligt hur kraven i grunden är liknande } \\
\text { dem för EUs ekologisk odling och har en jämförelse där } \\
\text { deras krav är hårdare än motsvarande krav i EUs } \\
\text { märkning. Alla underlag för certifiering ligger } \\
\text { lättillgängligt på websidan. Naturland är själva } \\
\text { certifierade för ISO } 17065 \text {. }\end{array}$ \\
\hline
\end{tabular}


bomullsproduktionen bättre för människorna som

Better Cotton är mycket svårt att utvärdera då det är ett producerar den, bättre för miljön den växer i och bättre för sektorns framtid genom att utveckla bättre bomull som en hållbar råvara. Better Cotton innebär att bönderna producerar bomull på ett sätt som bryr sig om miljön, minimerar de negativa effekterna av gödsel och pesticider samt bryr sig om vatten, jord, hälsa och livsmiljöer. Märkningen avser att bomull odlas på ett mer hållbart sätt än konventionell bomull, men saknar direk koppling till kläder och hemtextil som säljs med märkningen. Märkningen gäller alltså enbart odling av fiber.

Märkningen finns på produkter och websidor samti företagspresentationer. (n) https://bettercotton.org/

Företag som säljer textil Global gjord av bomull
Cotton made in Africa står för bomull producerad i Subsahara Afrika med respekt för människor och natur. Genom Cotton made in Africa får småskaliga bönder stöd att förbättra sina och sina barns livsvillkor. Barnarbete, farliga pesticider och GMO är förbjudna.

Märkningen avser att bomull odlas på ett mer hållbart sätt än konventionell bomull, men har in nödvändigtvis direkt koppling till kläder och hemtextil som säljs med märkningen. När ordet Organic läggs till i märkningen (som då även byter färg från röd till grön) är odlingen ekologisk enligt GOTS eller EUs kriterier för ekologisk odling. Märkningen gäller alltså enbart odling av fiber. Märkningen finns på produkter och websidor samt $\mathrm{i}$ företagspresentationer.

Information om märkningen finns på websidan https://www.cottonmadeinafrica.org/en/ omfattande material tillgängligt. Better Cotton är ett

system för generellt förbättrad produktion av bomull och har ingen direkt koppling till enskilda produkter. Istället betalas en avgift motsvarande en viss mängd Better Cotton-bomull. Miljönyttan är svårutvärderad då de flesta krav är formulerade som en prioriteringsordning snarare än absoluta krav. Ett exempel under "Crop protection" är att bredspektrumspesticider ska användas som sista utväg, men inte är förbjudna. Märkningen av enskilda produkter, trots tydliga regler om förklarande text i

märkningsguiden, kan lätt tolkas som att produkten som köps producerats på ett mer hållbart sätt vilket märkningen inte visar. I köpögonblicket är svårt att förstå vad märkningen står för. Det är även tillătet att definiera "hållbart inköpt bomull" som Better Cotton, certifierad ekologisk och återvunnen bomull och därmed likställa dessa med varandra (H\&M Sustainability Report 2017). Better Cotton besvarar även frågan om märkningen

konkurrerar med andra standarder och nämner då endast att tre standarder anses likvärdiga och godkänns av Better Cotton. Däremot nämns inte någon av de standardarer för ekologisk odling som finns tillgängliga. Det är möjligt att märka produkter i upp till tre års tid med enbart $5 \%$ Better Cotton-bomull säkrat givet att det sedan ökar vilket då snarare visare en framtida ambition än faktisk prestanda.

Märkningen är i grunden för social utveckling och inga starka miljöuttalanden görs. Genom helt manuell odling och endast bevattning via regnvatten fås en lägre klimatpåverkan och vattenanvändning jämfört med en standardprodukt. För tillägget "Organic" används GOTS eller EUs krav för ekologisk odling. Då reglerna för hur märkningen får användas inte finns publikt tillgängliga är det svårt att avgöra om presentationen av märkningen kan användas vilseledande då massbalans är tillåtet för användning av märkningen (d.v.s. att slutprodukten inte måste innehållla spårbar bomull från Afrika). Den

presentation som identifieras på www.bonprix.se i direk presentation som identifieras på www.bonprix.se i dire
anslutning till produkten är tydlig och korrekt medan deras sida om hållbara material har en tveksam presentation vilket tyder på osäkerheter i presentation. 


\subsection{Företagens egna miljöuttalanden (typ 2) utan krav på tredjepartscertifiering/-verifiering}

Tabell 3: Företagens egna miljöuttalanden (typ 2) utan krav på tredjepartscertifiering/-verifiering

\begin{tabular}{|c|c|c|c|c|}
\hline $\mathrm{Nr}$ & Märkning & Ägare & Användare & Marknad \\
\hline 1 & KCA & $\begin{array}{l}\text { Knowledge-Cotton } \\
\text { Apparel }\end{array}$ & $\begin{array}{l}\text { Knowledge-Cotton } \\
\text { Apparel }\end{array}$ & Danmark \\
\hline 2 & Aiayu & Aiayu & $\begin{array}{l}\text { Företagsnamnet } \\
\text { används som ett } \\
\text { miljöuttalande }\end{array}$ & Danmark \\
\hline 3 & Dedicated & Dedicated & $\begin{array}{l}\text { Företagsnamnet } \\
\text { används som ett } \\
\text { miljöuttalande }\end{array}$ & $\begin{array}{l}\text { Sweden and } \\
\text { global }\end{array}$ \\
\hline
\end{tabular}

Huvudbudskap, omfattning och mer information

\section{KCA är en egen märkning för produkter som inte passar in} befintliga certifieringar eller är i processen för att klara tredjepartscertifieringar. KCA används för att pressa gränser och utveckla hållbara produkter. Fiber och tyg kommer alltid från hållbara källor och följer våra höga krav på kvalitet och social compliance.

Märkningen gäller för kläder som säljs av företaget. Det finns inte tillräcklig information om kriterier för att avgöra vad märkningen inkluderar.

Märkningen används på websidorna för kläder.

Information om märkningen finns på websidan:

https://knowledgecottonapparel.com/blogs/sustainability/ certifications

Aiayu har som mission att en $100 \%$ ansvarsfull affärsmodell är det enda sättet att göra affärer med integritet.

Ursprunget av en produkt tillsammans med dess sociala och miljömässiga påverkan är lika viktigt som estetik.

Transparens och ansvar är nödvändigt och Aiayu arbetar med erkända standarder i mode som definierar miljö och social prestanda i leverantörskedjan.

Företagsnamnet används på ett sätt som kan ses som en märkning. Märkningen får antas gälla företagets samtliga produkter. Märkningen har delvis ett livscykelperspektiv. Information om märkningen finns på websidan:

https://www.aiayu.com/en/page/eco/

Vi har alla sett och hört de fruktansvärda rapporterna från dagens modeindustri, det är tydligt att det behövs ett

positivt alternativ. Industrin är den näst största förorenaren i världen och arbetsförhållandena är under all kritik för båd bomullsbönder och fabriksarbetare. Dedicateds vision är at vara det positiva alternativet, att alltid använda de mest hållbara materialen på marknaden och att säkra värdiga arbetsförhållanden för både bönder och fabriksarbetare. Vi säkerställer att detta inte bara är tomma ord genom att jobba med de strängaste certifieringarna på marknaden. Företagsnamnet används på ett sätt som kan ses som en märkning. Märkningen får antas gälla företagets samtliga produkter. Märkningens dokumentation visar endast på att märkningen rör fibrer och inte slutprodukter. Information om märkningen finns på websidan: https://www.dedicatedbrand.com/sv/philosophy
Kommentar

Syftet med märkningen förefaller gott då det är produkter som aspirerar på bättre miljöprestanda, me huvudbudskapet som anges ovan är i princip den enda information som finns om vilka krav som ställs. En webbsida listar vad företaget ser som hållbara material med delvis oklara grunder om varför de är hållbara. Det hävdas även att hållbara material har en positiv påverkan på miljön och KCA märkningen länkas felaktigt under tredjepartscertifieringar vilket saknas.

Denna typ av märkning är svårutvärderad eftersom alla produkters prestanda behöver utvärderas vilket inte rym inom denna studie. Företagsnamnet bygger på att alla deras produkter är certifierade för miljö eller social hållbarhet, zero waste och transporter. Alla bomullsprodukter är GOTS-certifierade, medan ulle saknar certifiering. Företaget har ett stort fokus på kvalitet och tidlöshet för att plaggen ska kunna leva länge. Alla miljöuttalanden har inte tydlig dokumentation och det finns mindre delar där det är oklart om miljöuttalandet stödjs av dokumentationen.

Hänvisning görs till GOTS-certifiering för bomull respektive GRS för användning av återvunnen polyester men applicerbara licensnummer för GOTS och GRS saknas på websidan vilket gör det svårt att vara säker $p$ certifieringen av enskilda produkter. Detta berör både transparens och dokumentation. För produkter med dessa märkningar som underlag är dock miljönyttan tydlig. Däremot hänvisningen att "jobba med de strängaste certifieringarna på marknaden" kan inte anses stämma för GRS som kräver minst $50 \%$ återvunnet material och det finns tuffare krav i till exempel Recycled Claims Standard - Recycled 100 som kräver 95\% återvunnet material. 

avgör vad som är okej.

Definierade och kontrollerade av externa organisationer ger certifieringarna en möjlighet att göra de mest

ansvartagande kläder vi kan. Certifikaten garanterar at Neutrals produkter är tillverkade enligt de högsta sociala etiska och miljömässiga standarderna. Det räddar inte världen. Det gör oss inte bättre. Men det är rimligt och det gör det okej.

Märkningen gäller kläder och har ett tydligt

livscykelperspektiv.

Märkningarna används på websidan och i produktfoldrar med komplett beskrivning.

Information om märkningen finns på websidan: https://www.neutral.com/certified-responsibility/

Det är svårt att definiera ett huvudbudskap för H\&M Conscious då det beskrivs i lösa termer. En pressrelease for kollektionen 2018 beskriver: H\&M:s Conscious Exclusive kollektion fortsätter att visa på innovativt och hållbart mode. Den innehåller accessoarer av återvunna ljusstakar och klänningar av gamla fisknät och annat nylonavfall. Den nehåller de nya hållbara materialen återvunnet silver och ECONYL ${ }^{\oplus}$, en 100 procent återvunnen nylonfiber tillverkad av fisknät och annat nylonavfall.

Märkningen används för en återkommande kollektion av kläder och accessoarer. Det är oklart vad märkningen inkluderar.

Märkningen används på plagg som ingår i kollektionen. Viss information om märkningen finns på websidan, men tydlig beskrivning saknas:

htps://about.hm.com/sv/media/news/general-news2018/h-m-conscious-exclusive-continues-to-show-proofof-sustainable-f.htm
Neutral säljer bara till företag och kommunicerar därmed inte till konsumenten direkt. Samtliga plagg är märkta med deras egen märkning och uppfyller därmed GOTS, EU-blomman, STANDARD 100 by OEKO-TEX och är tillverkade med egenproducerad förnybar energi (samt sociala märkningar). Märkningen beskrivs tydligt både en pedagogisk bild, en märkningsguide och på en websida med länkade licensdokument.

Det går inte att hitta någon tydlig definition av vad som räknas som Conscious och därmed vilken potentiell miljönytta som fås jämfört med en standardprodukt. Det går heller inte att utläsa av enskilda plagg som kan ha skrivningar som "av ekologisk bomull" (utan hänvisning till andel eller certifikat), del av plagg som innehåller återvunnen ull (utan hänvisning till certifikat), "Polyestern i tightsen är delvis återvunnen" (utan hänvisning till andel eller certifikat), "Jeansen är delvis tillverkade av

återvunnen bomull" (utan hänvisning till andel eller certifikat). Presentationen innehåller mycket om hållbara material utan tydligt beskrivning eller motivering varför dessa är hollty Manga breda och vaga formuleringar dessa arr hallbara. Mânga breda och vaga formuleringr Övergripande information om hållbara material och hållbarhet är främst fokuserat på framtida ambitioner. 


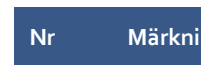

$6 \quad$ Skunkfunk

Ägare

Användare

Företagsnamnet

används som ett

miljöuttalande

Marknad

Vith

Vitro

och

Sydamerika

med hå att förändra modeindustrin och gör våra kläder

Vi integrerar hållbarhet med ett övergripande arbetssätt över alla våra processer. Gå med i den hållbara moderörelsen och köp damkläder med respekt för miljön. Företagsnamnet används på ett sätt som kan ses som en märkning. Märkningen får antas gällla företagets samtliga produkter. Märkningen har ett livscykelperspektiv. Information om märkningen finns på websidan: https://www.skunkfunk.com/en/care-for-everything

Företagsnamnet används som ett miljöuttalande
Finland inköp av kläder.

Företagsnamnet används på ett sätt som kan ses som en märkning. Märkningen får antas gälla företagets samtliga produkter. Märkningen berör i huvudsak fibrer i plaggen och har i vissa med stöd av GOTS ett livscykelperspektiv. Information om märkningen finns på websidan: https://www.nudge.fi/page/6/eettiset-ja-ekologiset valinnat-vaateostoksilla

\section{En del produkter är märkta med Responsible Fashion och} webshopen kan sorteras efter hållbara material. Märkningen gäller främst fiberval i kläder.

Information om märkningen finns på websidorna: https://www.kappahl.com/sv-SE/om-kappahl/hallbarhet/ https://www.kappahl.com/sv-SE/om-

kappahl/hallbarhet/produktansvar/hallbara-material/ https://www.kappahl.com/sv-SE/om-

kappahl/hallbarhet/hallbarhet/hallbarhetsrapport/

Dessa plagg är gjorda av certifierad ekologisk bomull. Ekologisk bomull odlas utan användning av skadliga bekämpningsmedel, kemikalier eller gödningsmedel. Märkningen gäller innehåll av ekologisk fiber i kläder. Märkningen finns på webshopen som är den enda information som finns:

https://www.flashwoman.se/organic
Hållbara val och gott humör - Etiska och ekologiska val för Vissa produkter är märkta och webshopen kan sorteras efter märkningen som urval.
Kommentar

För en del uttalanden finns information om vad de avser med hållbara material och hållbar produktion, men viss aspekter är svåra att hitta. Då det saknas tydlig information om vilka plagg som har vilka certifieringar och är producerade på vilket sätt är det svårt att bedöma om deras plagg överlag har en tydlig miljönytta jämfört med standardplagg. Klimatkalkylatorn saknar helt underlag eller information om beräkningssätt. Det är svårt att identifiera underlag för att stödja

påståendet att Skunkfunk är den hållbara moderörelsen eftersom kopplingen till vad enskilda plagg medför för miljönytta jämfört med en standardprodukt. När två olika märkningar (OCS och GOTS), med stora skillnader $\mathrm{i}$ kravnivå för ekologisk bomull används är det kritiskt att det går att urskilja vilka plagg som har vilket certifiering $\mathrm{i}$ grunden vilket inte går att utläsa för ett enskilt plagg

Det är inte helt tydligt vad nudge själva gör för att räknas sig som hållbara val. Enskilda produkter har i hög grad STANDARD 100 by OEKO-TEX och GOTS märkningar och ett fåtal produkter saknar någon av dessa märkningar hittades. Nudge redovisar tydligt både att konsumenten bör köpa färre kläder och hur märkningar påverkar miljönyttan och presentationen för enskilda plagg är helt tydlig kring vilka miljömärkningar som är aktuella och vilken miljönytta som därmed uppnås. Den övergripande kopplingen mellan informationen om hållbarhet och deras produkter är lite svår att identifiera.

Märkningen är inte tydligt förklarad någonstans. På enskilda plagg kan det vara ekologisk bomull eller Better Cotton bomull, där det senare inte är listat under hållbara material på websidan för hållbarhet. Better Cotton beskrivs däremot på sidan för "hålllbarhet för oss" bredvid en bild där texten $100 \%$ organic cotton tydligt kan utläsas på en skylt. Användningen av ekologisk bomull stöds av GOTS eller OCS.

Det är tydligt vilka produkter som omfattas och det stå hur många procent certifierad ekologisk bomull de innehåller. Det saknas dock helt dokumentation kring vem som certifierat bomullen som ekologisk eller enligt vilken standard detta gjorts. Detta gör i sin tur att miljönyttan inte kan analyseras. 


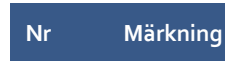

10 The good project Hållbar kollektion

Ägare

ginatricot

Användare

Anvandare

Marknad

Norden och

Tyskland

\section{Företagsnamnet} används som ett miljöuttalande
Huvudbudskap, omfattning och mer information

The Good Project - Hållbar kollektion innehåller kläder för

dig som värnar om miljön. Här finns kläder i hållbara material som håller länge och är miljövänligt framställda. Märkningen gäller främst fiberval i kläder.

Märkningen används på websidan och förklaras delvis i en bloggpost samt i hållbarhetsrapporten:

https://www.ginatricot.com/cse/kollektion/kollektioner/th e-good-project-hallbar-kollektion/ccollection-ccollectionschallbarkollektion-p1.html

https://www.ginatricot.com/se/sv/csr/what/articles/sustain able-materials

https://www.ginatricot.com/cms/system/csr/footer/pdf/G na\%20Tricot\%2oSustainability\%2oreport\%202017-2-.pdf

Ekologiska barnkläder från Villervalla är rätt val för dig som vill ha det bästa tänkbara för både ditt barn och för miljön. Villervallas ekologiska sortiment är tillverkade i garanterat giftfria material, och med samma höga kvalitet, långa

hållbarhet och fina design som Villervallas övriga sortiment. Plaggen är tillverkade i Oeko-Tex ${ }^{\oplus}$-certifierat eko-material vilket innebär att en oberoende organisation säkerställt att inga miljö- eller hälsofarliga ämnen finns i plaggen.

Märkningen gäller kläder och berör ekologisk odling av fiber och möjlig hälsopåverkan på användaren till följd av textilens emitterande ämnen vid användning. Märkningen används på websidan och mer information om märkningen finns på websidorna: https://www.villervalla.se/vara-klader/ekologiskt/ https://www.villervalla.se/om-oss

Earthpositive är en grön revolution i marknadsföringskläder: Klimatneutrala kläder.

Ekologisk bomull+Etisk handel+klimatneutral tillverkning = $100 \%$ Hållbart $=100 \%$ Earthpositive.

Företagsnamnet används på ett sätt som kan ses som en märkning. Märkningen får antas gälla företagets samtliga produkter. Märkningen har i stort sett ett

livscykelperspektiv, även om inkluderade faktorer är

beroende på vilka tredjepartscertifieringar som används för respektive plagg.

Information om märkningen finns på websidan: http://www.earthpositive.se/about.html
Kommentar

Det går inte att utläsa hur en enskild produkt är mer miljövänlig än en standardprodukt. I en bloggpost går det att utläsa att det som sorteras under hollbara material i webshoppen innehåller minst $50 \%$ hållbara material och hållbarhetsrapporten definieras hållbara material som hâlibarhetsrapporten definieras hăllbara material som hållbarhetsrapporten beskrivs även Better Cotton intill en bild med tydlig etikett med text "Certified organic cotton". Det saknas information om miljöaspekter för enskilda plagg, vem som certifierar material eller efter vilken standard.

Det saknas bevis eller certifikat för ekologisk bomul medan hänvisning görs till STANDARD 100 by OEKO-TEX för giftfrihet. Dock beskrivs OEKO-TEX-certifierat material på ett sätt som kan tolkas som att OEKO-TEX även garanterar ekologiskt material, vilket inte är korrekt. Relevanta STANDARD 100 by OEKO-TEX certifikat redovisas tydligt.

Earthpositive säljer bara till företag och kommunicerar därmed inte till konsumenten direkt. Det är tydligt vad märkningen avser och miljöprestandan är bättre än standardprodukter. Plaggen presenteras dock som $100 \%$ hållbara, vilket inte stödjs av dokumentationen. Plaggen presenteras som klimatneutrala, vilket underlaget inte visar. De förefaller ha väsentligt lägre klimatpåverkan än ett standardplagg, men det är inte klimatneutralt. Det hänvisas även till att de demonstrerar den högsta möjliga standarden för miljö, vilket inte tydligt stödjs.

Dokumentationen innehåller en tveksam hänvisning till vad STANDARD 100 by OEKO-TEX innebär samt att certifikatet för GOTS slutade vara giltigt 5 år tidigare. Metodiken för klimatberäkningarna är även bristfällig även om resultaten förefaller rimliga för de utsläppsminskande åtgärder som genomförts. 


\begin{tabular}{|c|c|c|c|c|c|c|}
\hline $\mathrm{Nr}$ & Märkning & Ägare & Användare & Marknad & Huvudbudskap, omfattning och mer information & Kommentar \\
\hline 13 & Sustainable Evolution & Tommy Hilfiger & Tommy Hilfiger & Global & $\begin{array}{l}\text { Clothes with benefits - You wardrobe essentials, now in } \\
\text { quality organic cotton. } \\
\text { Det är oklart vad märkningen avser. } \\
\text { Märkningen finns på plagg i webshopen. } \\
\text { Information om märkningen finns på websidan: } \\
\text { http://global.tommy.com/int/en/about/corporate- } \\
\text { responsibility/18 }\end{array}$ & $\begin{array}{l}\text { Plagg under märkningen är t.ex. märkta som ekologisk } \\
\text { bomull, utan hänvisning till bevis, eller märkta med } 43 \% \\
\text { återvunnen polyester, även här utan hänvisning till bevis } \\
\text { eller i vanlig polyester med certifierat dun-innehåll. Under } \\
\text { Sustainable Evolution under corporate responsibility } \\
\text { beskrivs användning av Better Cotton och arbete med } \\
\text { vatten och kemikalier som i de flesta fall är odefinierade } \\
\text { åtgärder eller bevisföring. En stor mängd breda, } \\
\text { odefinierade och vaga uttryck används för att beskriva } \\
\text { märkningen. }\end{array}$ \\
\hline 14 & ECO Friendly & Twilfit & Twilfit (i butik) & Sverige & $\begin{array}{l}\text { Butiksmärkning:ECO Friendly. } \\
\text { Märkningen berör troligen delvis ekologiskt odlad fiber i } \\
\text { kläder. Motsvarande plagg i webshopen är märkt som } 50 \\
\text { \% Ekologisk bomull. } \\
\text { Märkningen används i butik där ingen ytterligare } \\
\text { information fanns. Inte heller på websidan beskrivs } \\
\text { märkningen utan nedanstående länk visar ett plagg som } \\
\text { ingår i märkningen: } \\
\text { https://www.twilfit.se/varumarken/twilfit/t-shirt-emma- } \\
\text { heather-rose/ }\end{array}$ & $\begin{array}{l}\text { Märkningens betydelse är ej tillgänglig. Motsvarande } \\
\text { produkt online är delvis ekologisk bomull. Ingen } \\
\text { oberoende certifiering för ekologisk odling återfinns. Den } \\
\text { enda miljöinformation som ges handlar om bärkassar. }\end{array}$ \\
\hline 15 & $\begin{array}{l}\text { ECO - Environmentally } \\
\text { Concious Option }\end{array}$ & Polarn O. Pyret & Polarn O. Pyret & $\begin{array}{l}\text { Europa och } \\
\text { USA }\end{array}$ & $\begin{array}{l}\text { Sedan flera år tillbaka har vi märkt våra mer hållbara } \\
\text { produkter med vår ECO-märkning, Environmentally } \\
\text { Conscious Option. Märkningen tog vifram för att guida er } \\
\text { kunder till att göra ett mer hållbart val. Genom åren har vi } \\
\text { börjat använda allt fler hålllbara material och certifieringar, } \\
\text { och vår märkning har kommit att innefatta allt mer. Idag } \\
\text { har vi ett sortiment som till } 58 \text { \% består av mer hållbara } \\
\text { produkter. } \\
\text { Märkningen avser främst fiberval i kläder, men då den är } \\
\text { under avveckling är det svårt att avgöra. } \\
\text { Information om märkningen finns på websidan: } \\
\text { https://www.polarnopyret.se/popcares/markning }\end{array}$ & $\begin{array}{l}\text { Märkningen är under avveckling för att bytas ut mot med } \\
\text { specifik information om vilka material eller certifieringar } \\
\text { som gör plaggen hållbara. } \\
\text { Presentationen och indelning i olika kategorier är rörig då } \\
\text { märkningarna överlappar stundtals, men de ger en tydlig } \\
\text { förklaring till detta. Det är dock tydligt om ett plagg är } \\
\text { märkt med GOTS (med referensnummer), Better Cotton } \\
\text { eller liknande i flera fall. Man beskriver även kategorin } \\
\text { som "mer hållbara produkter" och inte "hållbara } \\
\text { produkter" vilket är en relevant distinktion. }\end{array}$ \\
\hline 16 & $100 \%$ Organic Cotton & Monki (H\&M) & Monki & Global & $\begin{array}{l}\text { Alla våra Denim-produkter är } 100 \% \text { e kologiska. } \\
\text { Märkningen gäller användning av ekologiskt odlad fiber i } \\
\text { kläder. } \\
\text { Märkningen finns på websidan och information finns på } \\
\text { websidan: } \\
\text { https://www.monki.com/we-are-monki/monki- } \\
\text { cares/material/ }\end{array}$ & $\begin{array}{l}\text { Det går lätt att hitta att ekologisk bomull certifieras enligt } \\
\text { antingen OCS eller GOTS. Dock finns inga certifikat eller } \\
\text { hänvisningar till referensnummer vilket gör att det går att } \\
\text { avgöra vilka plagg som klarar vilken certifiering. }\end{array}$ \\
\hline
\end{tabular}


Med start I host är $100 \%$ av vår bomull köpt från hållbara källor, för alltid. Ett litet steg mot vårt mål att bara använda àtervunnen eller på annat sätt hållbart inköpt material till 2030. Men Monki Cares är mer än bara hållbara material, det handlar om hur vi kan göra hela vår affär mer hållbar. Märkningen gäller fiberval där bomull i kläder ska komm från mer hålllbara källor.

Information om märkningen finns på websidan: https://www.monki.com/we-are-monki/monkicares/material/

Märkningen visar på plagg som har inslag av mer hållbara material som lyocell eller ekologisk bomull. Märkningen gäller fiberval i kläder. Märkningen används på websidan och information om märkningen finns på websidan:

https://info.stockmann.com/inspiroidu/naiset/muoti/stock mannin-omat-merkit-tarjoavat-vastuullisia-valintoja/

Norge, Sverige Finlan

Stormberg arbetar aktivt med att minska miljö-och Klimatpåverkan i samband med sin verksamhet. Klimathandlingsplanen ger en översikt över några av de åtgärder som man redan tagit tag i men Stormberg arbeta mot en nollvision. Vi har en bit kvar till det målet. Stormberg har därför valt att kompensera sitt $\mathrm{CO}_{2}$ - utsläpp genom att köpa FN-godkända klimatkompensationer så att klimatpåverkan från produktionen blir desamma som om produktionen inte hade ägt rum.

Märkningen gäller ett företag och endast klimatpåverkan. Märkningen används på websidan och information finns på websidan:

https://www.stormberg.com/se/om-

stormberg/miljo/klimatneutralt-foretag

Play Fair-Organic Intersport $\quad$ Intersport Etirel Global
Cotton

Butiksmärkning: Etikett med "Play Fair - Intersport.se" på ena sidan, "Organic cotton" på andra sidan.

Märkningen gäller fiberval $i$ kläder och på websidan ses att motsvarande plagg är märkt med $100 \%$ ekologisk bomul. Beskrivning av märkningen saknas både i butik och på webben. Länken nedan visar ett plagg där märkningen används:

https://www.intersport.se/klader/pikeer/8848-alt-corppique-herr/blue
Märkningen klassar hållbart inköpt bomull som ekologisk bomull, Better Cotton eller återvunnen bomull vilket gör att miljönyttan varierar stort. Ekologisk bomull stärks av OCS eller GOTS certifieringar (dock utan angivna OCS eler GOTS certierngar (dock tan angivna referensnummer) och aterunnen bomull av GRS/RCS. Marrkningenar valdigttydig med att likstalla ekologisk bomull med Better Cotton trots att dessa har kraftigt olika nivåer på kravställning: "sustainably sourced cotton is to organic, recycled or Better Cotton what the word fruit is to pears, oranges and apples. They are all fruits. Great fruits. Just different types." Det går inte att utläsa vilka produkter som berörs av vilken märkning.

Det är oklart hur stor andel av plaggen som är ekologisk bomull samt hur den certifierats och det verkar inte finnas någon gräns för minsta andel lyocell för att plagget ska inkluderas vilket sammantaget gör miljönyttan osäker. Själva märket antyder överdriven miljönytta genom valet av order "hållbar" snarare än "mer hållbar" men det redovisas ändå tydligt att ambitionen är lägre Det finns inga certifieringar eller annat underlag som stödjer märkningen.

Det finns mycket tillgänglig information om beräkningssätt och det presenteras helt transparent med datakällor, men det finns en osäkerhet kring ett inaktuellt certifikat. Det senaste publicerade certifikatet som hittas under länken "Gällande klimatcertifikat" är 7 år gammalt och det är därför tveksamt om informationen fortfarande ärkorrekt Ur perspektivet transparensen blir det därmed oklart om stödjande certifikat kan anses finnas.

Det saknas helt information om vad märkningen inkluderar både i butik och på websida mer än att den innehåller ekologisk bomull (i butik okänd andel, på web $100 \%$ ). Detta stöds inte med någon form av verifierin eller certifiering vare sig vid produkten eller under företagssidorna kring miljö. 
För oss handlar hållbarhet om att ta hänsyn till vår planet och alla som bor där. Det finns många aspekter av modebranschen som kräver hållbart tänkande, från etiska arbetsvillkor till miljöpåverkan och djurskydd. Det här är ett ämne som vi tycker är väldigt viktigt och därför har v plockat ihop ett urval av specialmärkta produkter och hållbara varumärken för att göra det enkelt för dig at handla hållbart.

Märkningen gäller olika aspekter på kläder eller fiberval och används för att kunden ska kunna identifiera främst produkter med andra märkningar.

Märkningen används på websidan för att sortera fram produkter med olika hållbarhetsmärkningar.

Information om märkningen finns på websidan: https://www zalando se/hallbart-mode/ utvecklar nya lösningar.
Nu gör vi det även enklare för dig att göra ett medvetet val när du handlar Tierrakläder genom symbolen Medvetet val, eller Conscious Choice.

Symbolen sätter vi på produkter som vi är extra stolta över ur ett hållbarhetsperspektiv. Vi höjer dessutom hela tiden ribban för vad vi kallar Medvetet val allteftersom vi

Märkningen gäller olika aspekter för kläder eller fibrer och har inte ett livscykelperspektiv.

Märkningen används på websidan och förklaras på websidan:

https://tierra.se/miljoarbete/medvetet-val/

B.Tomorrow är en märkning som leder dig till en hållbar Björn Borg-produkt. Delta I vårt arbete för en bättre morgondag!

Märkningen gäller troligen fiberval i kläder

Märkningen används på websidan och förklaras delvis på: https://corporate.bjornborg.com/en/section/sustainability/
De flesta produkter som har märkningen har en förklarande text om vilken miljöaspekt som gjort att plagget räknas under hållbarhet. Det är tydligt att hollb hallbarhetsperspektivoch att varje underliggande märkning făr stå for sig. Ett antal klàdmärken sakna forklaringen och hänvisningen till att märket i sig tar hänsyn till hållbarhet, t.ex. Nudie och Filippa K vilket är en brist eftersom det inte förklaras någonstans utan man får gå in på deras respektive websidor för att läsa sig till hur de tar hänsyn till miljön. Miljönyttan för märkta produkter är generellt högre än standardprodukt men det finns ett spann för inkluderade märkningar. Då det transparent visas vilken som är aktuell för plagget blir det tydligt för konsumenten vad som gäller för det enskilda plagget. En beskrivning av Better Cotton saknas där övriga märkningar redovisas trots att den ingår i märkningen.

Det beskrivs tydligt vilka aspekter som krävs för märkningen och varje enskild aspekt beskrivs. Miljönyttan är sannolikt bättre än en standardprodukt. Det finns enskilda krav som i sig inte nödvändigtvis ar bättre, men då två krav i kombination krävs och då dessa beskrivs för varje produkt har inga tveksamma fall beskrivs for varje produkt har inga tveksamma fall identifierats. Det saknas referensnummer för GOTS-
märkningen och det går inte att få fram vilken OEKO-TEX märkning som avses.

Beskrivningen av vad märkningen innebär är en stor samling av målsättningar, ett fåtal konkreta åtgärder och delvis motsägelsefull information. För de enskilda produkter som identifierats beskrivs $100 \%$ ekologisk bomull, men ingen verifiering eller certifiering

presenteras. Att B-Tomorrow leder till en hållbar produkt är oklart då det inte bevisas eller visas vad som gör produkten bättre än en standardprodukt. Vad som anses som hållbara fibrer definieras enligt klass A och B $i$ MADE-BY benchmark för fibrer, men samtidigt finns en målsättning att $70 \%$ av plaggen ska klara detta till 2019 samtidigt som $75 \%$ av bomullsplaggen ska vara Better Cotton till 2021 (Better Cotton räknas ej som klass A eller B) vilket inte är kompatibelt då $86 \%$ av plaggen är bomull. 
För att göra det enklare för dig som kund som vill handla mer hållbart mode och heminredning så har vi skapat miljöstämpeln "A better choice". Produkter med denn stämpeln är tillverkade med hänsyn till miljön genom mer

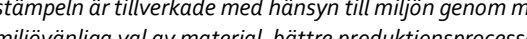
movan liga val av material, battre produktionsprocesser med lägre resursforbrukning eller återanvända produkter från Vintage Collection

Märkningen gäller främst fiberval i textil och har i de flest fall inte ett livscykelperspektiv.

Märkningen används för att sortera mer hållbara val på websidan och förklaras på websidan:

https://www.ellos.se/page/sustainability/a-better-choice

Det mest miljövänliga skulle vara om vi alla gick nakna odlade vår egen mat och frågade magkänsla för råd istället för ett Silicon Valley-baserat orakel. Vår miljöpolicy når int så långt. Vi gör fortfarande jeans. Det är vår passion. Och det är 2018. Men vi valde att tillverka vår produkt på ett rättvist och etiskt sätt. En möjlighet varje företag ges, men förfå tar.

Företagsnamnet används på ett sätt som kan ses som en märkning. Märkningen får antas gälla företagets samtliga produkter. Märkningen har ett livscykelperspektiv.

Information om märkningen finns på websidan: https://www.nudiejeans.com/page/this-is-nudie-jeans

Dina modefavoriter producerade med omsorg för människor och miljö. Hållbara och ekologiska kläder tillverkade i ekologiskt eller ansvarsfullt odlad bomull, Tencel eller återvunna material så som bomull, ull, polyester och polyamid.

Märkningen gäller fiberval i kläder.

Märkningen används i butik och på websidan. Information om märkningen finns på websidorna nedan och $i$ hållbarhetsrapporten:

https://www.lindex.com/se/dam/sustainablechoice/\#!/page1/row1

https://about.lindex.com/se/sektion/hallbarhet/

"Hållbarhet skall vara enkelt."

För att det ska bli ännu enklare att välja rätt gör vi allt förarbete. Viförsöker köpa material och produkter som har tagit hänsyn till människor och miljö i produktion. Märkningen används för att kunna sortera ut mer hållbara produkter med andra främst tredjepartscertifierade märkningar. Märkningen kan därmed avse endast fibrer eller ha ett livscykelperspektiv.

Märkningen används på websidan och information om märkningen finns på websidan:

https://www.ahlens.se/cms/20160829_141831
Kommentar

För vissa produkter anges inte detaljer kring vilken miljöaspekt som avses men beskrivningen av vad Ellos inkluderar generellt är tydlig. För de flesta plagg finns en större miljönytta än standardprodukter, men då det saknas referensnummer för de certifieringar som

hänas referensnummer for de certifieringar som
hänvisas till och vissa plagg i bomull saknar information hanvisas till och vissa plagg i bomull saknar inform om det är Better Cotton, GOTS eller OCS samt i
kombination med att det krävs $50 \%$ av det hållbara materialet är det svårt att avgöra vad miljönyttan är med olika plagg. Positivt att märkningen indikerar en "bättre" prestanda istället for en "bra" prestanda.

Det redovisas tydligt vilka miljöaspekter som inkluderas inklusive ekologisk bomull (och vilka certifieringar som används), återvunnet material (med visst stöd av certifieringar), gratis reparationer för längre livslängd, återtillverkning och återförsäljning av produkter. Miljönyttan är tydlig och verifierad även om det saknas referensnummer så visar man istället att man är deltagande medlem i organisationen som tagit fram dem vilket gör det osannolikt att de inte finns. Man är helt transparent med sin leverantörskedja och verkar använda certifieringar där så är möjligt

Det är svårt att följa vad som avses med ansvarsfullt odlad bomull samt i vissa fall hur stor andel av ett plagg som är återvunnen råvara. Detta gör att miljönyttan i vissa fall är osäker iämfört med en standardprodukt när andra märkningar saknas. I hållbarhetsrapporten anges att GRS och RCS används men detta syns inte på

produkterna. Flertalet plagg är certifierade som ekologisk bomull. Formuleringen "Hållbara och ekologiska kläder tillverkade i ekologiskt eller ansvarsfullt odlad bomull" är tveksam eftersom ekologiska kläder rimligtvis är tillverkade av ekologiskt certifierade material. Det är svårt att följa vilka krav som gäller för vilka produkter.

Märkningen samlar flera andra certifieringar och märkningar som underlag. Miljöambitionen är inte konsekvent i den högre skalan, men det är tydligt bättre än standardprodukterna och det är mycket tydligt var nivån är för varje produkt eftersom den enskilda miljöaspekten eller livscykelperspektivet beskrivs för varje produkt genom ytterligare märkning. 


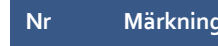

28

Fonnesbech

Användare

Fonnesbech - Organic,

Made in EU, Fair
Varje plagg är märkt med en (eller flera) symbol för vilken miljöpåverkan som produkten tagit hänsyn till - ekologiskt àtervunnen, hudvänlig, tillverkad i EU, uppförandekod. Märkningen gäller fem olika aspekter och har i vissa fall et livscykelperspektiv och i vissa enbart enstaka miljöaspekter inkluderade.

Märkningen används på websidan och information finns på: https://fonnesbech-cph.com/responsibility/

Viär många som gillar att klä oss i mjuk, härlig bomull. Då är det bra att veta att vi kan välja kläder i ekologisk bomull. Den ekologiska bomullen odlas utan användning av giftiga kemiska bekämpningsmedel, utan konstgödsel och utan genmodifierade frön. Vid produktion av ekologisk bomull använder bönderna de lokala resurserna på ett förnybart och långsiktigt sätt. För att kallas ekologisk måste bomullen vara certifierad. Den är tillverkad av bomull som har uppfyllt de strängaste kraven för märkningen. Hos oss är en stor del av kläderna märkta med ekologisk bomull.

Märkningen gäller fiberval genom användande av

ekologisk bomull.

Märkningen används på websidan och information om märkningen finns på websidan för Cubus och för ägaren Varnergruppen:

https://cubus.com/sv/foretaginfo/Om

Cubus/hallbarhet/ekologisk-bomull/

http://varner.com/no/sustainability/miljoe/

Aware - Ett mer hållbart modeval. Aware är en mer hållba fristående kollektion av åtråvärda plagg med bibehållen kraft utifrån en önskan att vara mer medveten om små vardagliga val.

Det är oklart vad märkningen innebär.

Märkningen används på websidan.

Information om märkningen finns på websidorna

https://www.veromoda.com/se/sv/vm/editorials/aware/

http://about.bestseller.com/sustainability/sustainability-

in-bestseller

Information på enskilda plagg: Organic, Ledig bastopp ekologisk bomull, melerad jersey i mjuk bomullsblandning, med ekologisk bomull, ekologisk bomull: bomull från kontrollerad ekologisk odling.

Märkningen gäller fiberval i kläder.

Märkningen används på websidan och ingen ytterligare information finns. Länken nedan visar ett plagg som har märkningen.

https://www.esprit.se/dam-trojor/ledig-bastopp-i-

ekologisk-bomull-g98EE1K804_001
Kommentar

Märkningen bygger delvis på certifieringar men det saknas underlag forr de som inte har certifieringar. Det finns frågetecken kring exakt vilka krav som ställs om produkter endast har Organic märkningen eftersom användandet av GOTS är krav under Skin Worthy märkningen. I övrigt listas tydligt vilka kriterier som gäller vilka plagg. Det är även intressant att de lyfter produktion i EU - under EUs ofta tuffare lagstiftning - som ett hållbarhetsargument.

Märkningen är tydligt presenterad och stöds av certifiering av antingen OCS eller GOTS. Dessa märkningar har olika kravnivåer men det som hävdas för märkningen stöds av båda dessa. Informationen att det är dessa certifieringar som används står inte på Cubus hemsida utan på dess ägare Varnergruppen.

Vero Modas webbsida ger ingen information om vad som gör kollektionen mer hållbar. Enskilda plagg innehåller til viss del återvunna material, ekologisk bomull (utan identifierad certifiering) och till viss del lyocell. I Bestsellers hållbarhetsrapport återfinns att kraven ä lyocell, ekologisk bomull, återvunnen bomull eller återvunnen polyester men ingen information om verifiering, certifiering eller minsta andel av plagg som måste vara av dessa material. Positivt att formuleringen "mer hållbart" används istället för "hållbart". Det är svårt att hitta dokumentation om märkningen.

Det saknas helt information om verifiering, certifiering av ekologisk bomull. Produkten benämns även som "i ekologisk bomull" när $40 \%$ av plagget är gjort av polyester. Miljönyttan går inte att utvärdera eftersom inget stödjer påståendet om ekologisk. 
Varje produkt är även märkt med vilken miljöaspekt som

Märkningen används för att kunna sortera ut mer hållbara produkter med andra främst tredjepartscertifierade märkningar. Märkningen kan därmed avse endast fibrer eller ha ett livscykelperspektiv.

Märkningen används på websidan och information om märkningen finns på websidan:

https://www.hemtex.se/info/hallbarhet/den_hallbara_trad

r relevant för just denna produkt och kopplar till redjepartsmärkning Miljönyttan varierar mella produkterna, men de produkter som studerats har varit minst STANDARD 100 by OEKO-TEX eller certifierat ekologisk bomull. STANDARD 100 by OEKO-TEX är inte listat under förklaringen för märkningen trots att vissa plagg enbart har denna märkning. Det står även det under märkningen att GOTS eller OCS certifierar all att det enbart är GOTS.

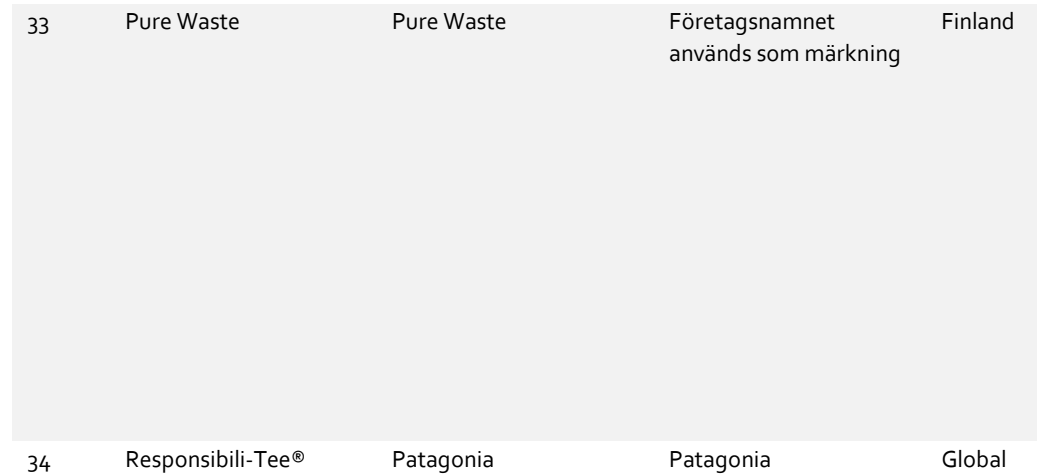

Pure Waste vet att allt vi gör har en påverkan på någonting någonstans. Vi vet att hållbarhet och kvalitet går hand $i$ hand. Vi tror att mode och miljömässigt tänkande ska gå hand $i$ hand också. Vi var beslutsamma att göra endast miljömässigt och i övrigt etiska val, utan kompromisser. Så när vi inte kunde hitta ett tyg som var $100 \%$ återvunnet, utvecklade vi ett själva.

Företagsnamnet används på ett sätt som kan ses som en märkning. Märkningen fo̊r antas gälla företagets samtliga produkter. Mäkning gäler fiberval i produkter iform av produkter. Mânkningen găller fiberva

formation om märkningen finns på websidorna:

https://www.purewaste.org/company/about-us.html https://purewastetextiles.com/

Responsibili-Tee är tillverkad av $50 \%$ återvunnen bomull och $50 \%$ återvunnen (post consumer) polyester som minskar behovet av olja för råmaterial och minskar avfallet till förbränning och deponi.

Märkningen avser fiberval genom användning av återvunnen råvara.

Märkningen finns på websidan och information delvis direkt på produktsidan och i mer detalj via länkade sidor: https://www.patagonia.com/product/mens-p-6-logoresponsibili-tee/39174.html?dwvar_39174_color=CADB https://www.patagonia.com/materials-tech.htm

Hela företaget bygger på egen produktion av textil och kläder från återvunnet produktionsspill. Det finns ingen oberoende certifiering av kedjan men den är förhållandevis transparent. Det är tydligt att företaget tillverkar av $100 \%$ återvunnet material.

Dokumentationen om källor till råmaterial hade varit ökat transparensen eftersom tredjepartscertifiering saknas.

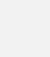

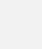

Patagonia visar inte på någon certifiering men redovisar material och använder Teijin för återvinning av sina egna produkter samt produktion av material för nya produkter. Dokumentationen är omfattande och verkar trovärdig men kan möjligtvis vara svåröverblickbar. Miljönyttan är sannolikt tydlig. 
Du kanske har noterat att artiklar i vårt sortiment är märkta med Sustainable Choice. Eller kanske har du sett

Sustainable Choice-logotypen på vår hemsida. Sustainable Choice är vår egen märkning av produkter som uppfyller en bestämd hållbarhetsnivå när det gälller tillverkning och design. Märkningen betyder att produkten uppfyller minst ett av följande hållbarhetskriterier: Bluesign certifierad, tillverkad av återvunnet material eller tillverkad av organisk bomull.

Märkningen avser antingen fiberval genom ekologiskt odlad fiber eller återvunnen fiber alternativt Bluesigncertifierad produkt.

Märkningen används på websidan och information finns delvis på websidan och delvis i hållbarhetsrapporten: https://www.haglofs.com/se/sv-

se/sustainability/sustainable-choice/

https://www.haglofs.com/se/sv

se/sustainability/sustainability-report/

Till våra hållbara produkter väljer vi endast material som uppfyller våra höga krav på skydd av människor och natur. Märkningen gäller fiberval för kläder.

Information om märkningen finns delvis på produktsidan på websidan och delvis på egen websida: ttps://www.bonprix. ansvar/produkter/haallbara-material/

\section{Kommentar}

Det är lätt att hitta vad som avses gällande kläder, men det är svårare att hitta dokumentation som stödjer märkningen. Miljönyttan av Bluesign är osäker och även om det nämns standarder för återvinning och ekologisk bomull är det inte tydligt hur dessa kopplar till specifika produkter. All bomull beskrivs som organisk, men man får anta att ekologisk avses. Det är dock oklart vilken standard som avses och hållbarhetsrapporten visar på flera olika nivåer.

Det är lätt att hitta vilken miljöaspekt som avses och varje plagg är märkt även med vilken aspekt som är aktuell för detta plagg Att mäka det som holltara produkter styrs detta plag. Attmarka detsom aspekt somaraktuel for inte av dokumentationen aven om det finns en miljönytta jämfört med en standardprodukt. För Cotton made in Africa behöver inte bomullen vara spårbar vilket gör att produkten inte måste innehålla just denna bomull. Ekologisk bomull stöds av GOTS eller OCS. Användning av återvunnet material stöds inte av certifieringar.

Green Cotton säger sig producera plaggen så miljövänlig som möjligt vilket de förklarar övergripande vad de innebär i varje produktionssteg. All fiber är certifierad

En företagsgrupp som skapade världens första certifierade ekologiska T-shirt ibomull. Vi tror på att göra skillnad genom att bry oss om människor, planeten och välstånd. I Green Cotton Group vill vi vara kända för att tillverka textil å miljövänligt som möjligt och vi gör detta genom att vara ärliga, trovärdiga och genom att använda de mest hållbara och omtänksamma produktionsmetoderna i varje del av produktionen.

Märkningen gäller kläder och har ett livscykelperspektiv. Information om märkningen finns på websidorna http://green-cotton.com/greencotton/

http://green-cotton.com/greencotton/sustainability/ http://greencottongroup.com/greencottongroup/privatelabel-sales/quality/ ekologisk och de använder sig av GOTS, OEKO-TEX Informationen är lite svåröverblickbar då flera hänvisningar till mer information leder till samma formuleringar i ett annat format istället för mer tydlig dokumentation och underlag. standard 100 och Bluesign för at stödja sina påståenden. 


\subsection{Miljövarudeklarationer (typ 3)}

Tabell 4: Miljövarudeklarationer (typ 3)

$\mathrm{Nr}$ Märkning Ägare

Användare

Huvudbudskap, omfattning och mer information

EPD International

Producenter av

textilprodukter

(sate

Sverige)

Miljövarudeklaration (Environmental Product

Declaration - EPD) är ett dokument som kommunicerar

verifierad, transparent ochjämförbar information om

produkters miljöpåverkan under hela livscykeln.

Märkningen har ett livscykelperspektiv och gäller i det

identifierade fallet sjukhuskläder. Märkningen redovisar

miljöprestanda, men ingen specifikt uppnådd nivå.

Information om märkningen finns på websidan:

https://www.environdec.com/What-is-an-EPD/

https://www.environdec.com/Detail/?Epd=14236
Kommentar

EPD används främst i företag till företagskommunikation men kan även användas gentemot konsumenter. Studien har inte identifierat något fall där en textilprodukt kommuniceras mot konsumenter utan endast produkter i form av kläder för sjukhuspersonal, men det är fullt

möjligt att göra. En EPD kommunicerar en miljöprestanda som är livscykelbaserad och beräknad efter detaljerade regler och medför därmed inte en miljöprestanda bättre an en standardprodukt utan en transparent och rimligt rättvis bas för jämförelse. 


\section{Summary in English}

This report addresses Eco-labelling and certifications used on home textiles and clothing in the Nordic market. The study has created a knowledge base about the environmental labels used for textiles in the Nordic region; how they are used and how they can contribute to a reduced environmental impact. The study provides a structured and clear inventory of the labels currently in use, which can be used as a basis for further studies and to support work within governmental and non-governmental national consumer organizations.

The inventory includes 56 labels and environmental statements.

An eco-label may affect an individual environmental aspect or cover an entire production chain with aspects in chemicals, energy use, production emissions, and emissions during use etc. As such, this study is not designed to determine which labelling puts the highest demands on a product. A correctly applied eco-label indicates a specific environmental impact category where the labelled product has a better performance than the corresponding standard product on the market. 
Nordiska ministerrådet

Nordens Hus

Ved Stranden 18

DK-1061 Köpenhamn

www.norden.org

Miljöpåståenden för textilier på den Nordiska marknaden

Rapporten kartlägger en stor mängd av de miljömärkningar och miljöuttalanden som används framförallt på hemtextil och kläder på den Nordiska marknaden. Syftet med studien har varit att samla ett kunskapsunderlag kring vilka miljömärkningar och miljöuttalanden som används på textil i Norden; hur de används och hur de kan bidra till en minskad miljöbelastning. Kartläggningen inkluderar totalt 56 märkningar och miljöuttalanden. Arbetsgruppen Hållbar konsumtion och produktion (HKP) under Nordiska ministerrådet för miljö och klimat har initierat detta projekt med avsikten att scanna av den nordiska textilmarknaden med fokus på de märkningar eller miljöpåståenden som konsumenten möter. Arbetsgruppen anser att vidare och djupare studier behövs för att analysera och värdera varje märke/påståendes positiva, negativa eller "ingen påverkan alls" effekt. 